\title{
Health Evaluation of Columbian White-tailed Deer on the Julia Butler Hansen Refuge for the Columbian White-tailed Deer
}

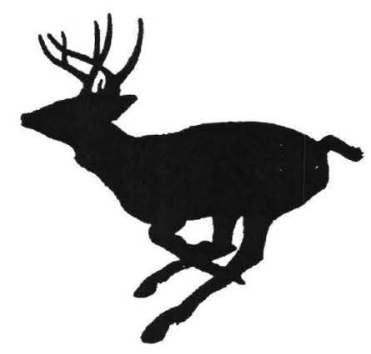

Terry Creekmore, M.S. and Linda Glaser, D. V.M.

U.S. Geological Survey

National Wildlife Health Center

6006 Schroeder Road

Madison, WI 53711-6223 


\section{Table of Contents}

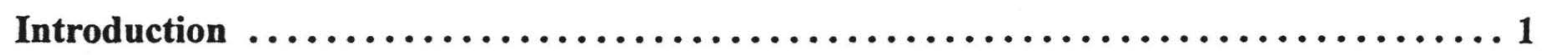

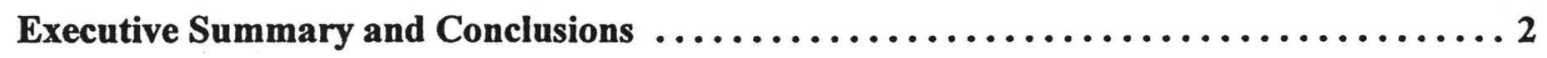

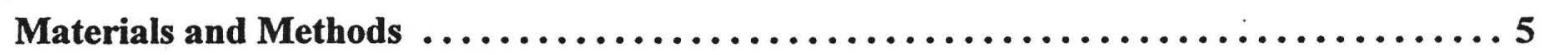

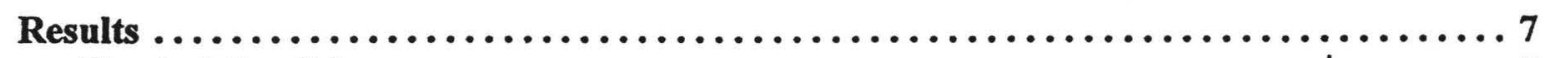

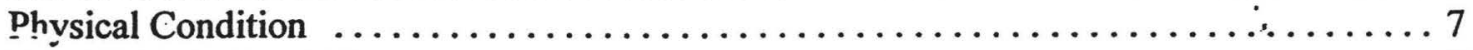

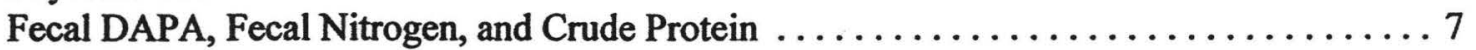

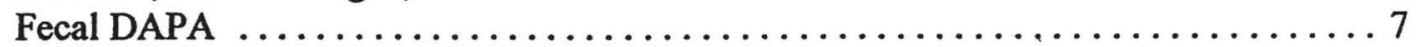

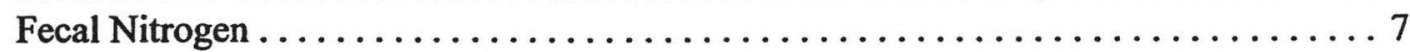

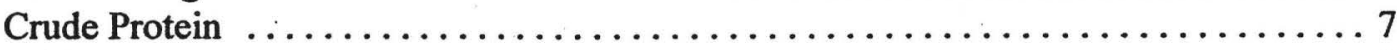

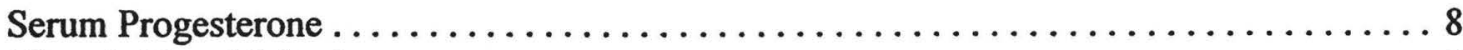

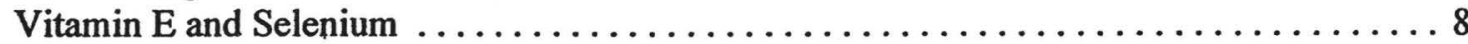

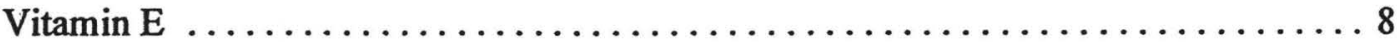

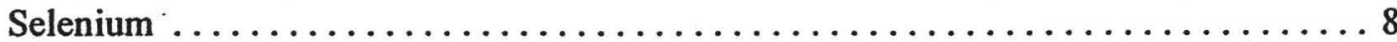

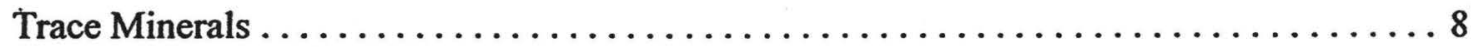

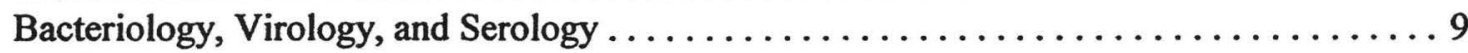

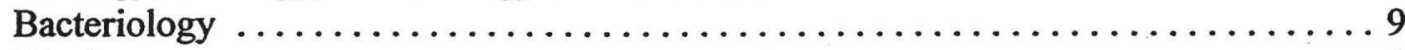

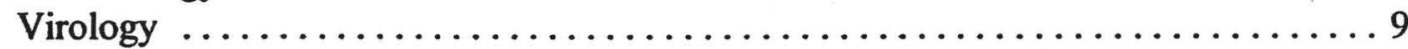

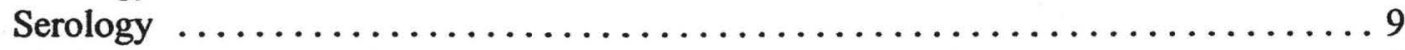

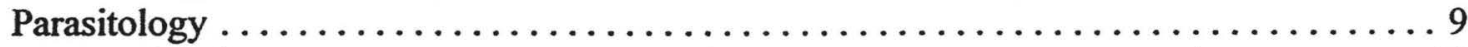

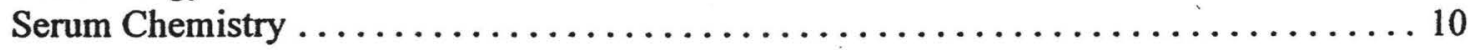

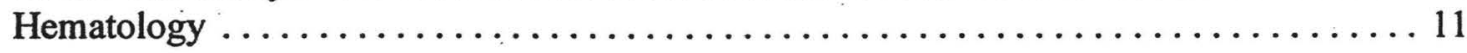

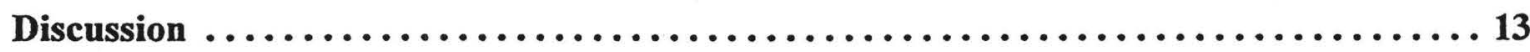

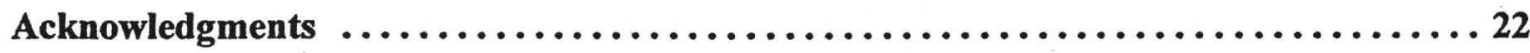

Tables....................................................23

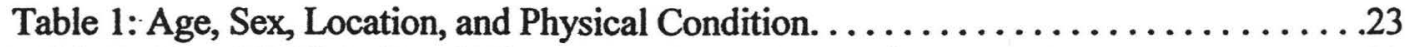

Table 2: Fecal DAPA, Fecal Nitrogen, and Crude Protein. .............. 23

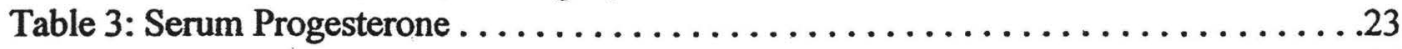

Table 4: Vitamin E and Selenium $\ldots \ldots \ldots \ldots \ldots \ldots \ldots \ldots \ldots \ldots \ldots \ldots \ldots \ldots \ldots \ldots \ldots \ldots, 24$

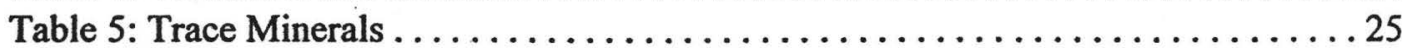

Table 6: Leptospira Serology ............................... 26

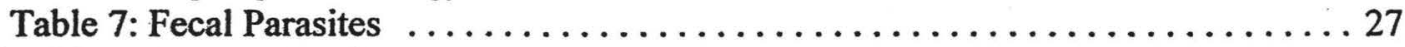

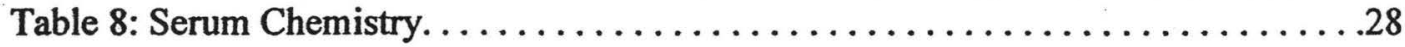

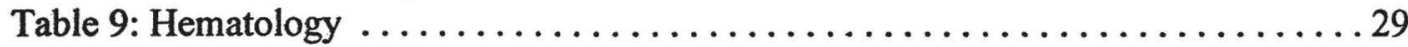

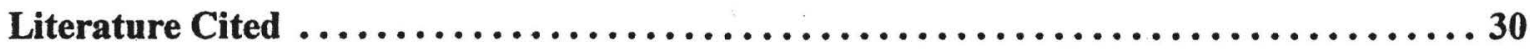




\section{1}

\section{- Introduction}

The Columbian white-tailed deer (Odocoileus virginianus leucurus) was designated an endangered species in 1968. At that time the estimated population along the lower Columbia River of Washington and Oregon was 300 to 400 deer (Gavin, 1984). The Julia Butler Hansen Refuge for the Columbian White-tailed Deer was established in 1972 to protect Columbian white-tailed deer and associated habitat. Currently, an estimated 600 deer are present in several separate populations. The total refuge population is estimated at 200 animals. Of those, the mainland population consists of approximately 60 animals while the largest refuge island (Tenasillahe Island) supports about 120 animals. The remaining 420 deer are present on private lands near the refuge (Al Clark, pers. com.).

Higher than expected deer mortality on Tenasillahe Island in the spring of 1996 prompted refuge personnel to request assistance from the National Wildlife Health Center (NWHC) for diagnostic evaluation to determine the cause of the mortalities. The mortality event occurred in the wake of extraordinary flooding that reduced the availability and quality of forage on the island. It is estimated that $50 \%$ of the deer population on the refuge died during this time period. The basic finding of emaciation attributable to probable starvation raised concerns regarding the health status of the deer herd, available food resources, and current population levels.

A health evaluation was conducted on free-ranging deer from the refuge in February, 1998. This evaluation was an analysis of physiologic parameters obtained from live deer in an attempt to determine the health of individual animals and, with adequate sampling, the health of the population. This study was conducted during February to examine individual animal health during the seasonal period when the deer are in their poorest physical condition. The late winter period prior to spring green-up is a time when the effects of breeding and winter stress are most evident (Verme and Ozoga, 1971).

The objectives of this study were to: (1) gather baseline physiologic data on a subset of the population, (2) evaluate the data to determine the health of the animals sampled, (3) if possible, identify causes of poor health and, (4) provide refuge personnel with information that will aid them in managing the population. 


\section{2 \\ Executive Summary and Conclusions}

The timing of this study was fortuitous in that it provided an opportunity to examine whitetailed deer from the refuge before they had recovered from the effects of winter undernutrition but after the start of spring green-up. This allowed us to evaluate winter nutrition based on fat reserves and spring nutrition based on fecal and serum nutritional indices that reflected the quality of the forage at the time of capture.

The primary concern during this study was the well being of the study animals. The sampling protocol was devised to gather the most valuable information in the shortest possible time to limit capture stress. This approach precluded the gathering of accurate weights and exact ages and limited sampling to relatively noninvasive techniques. The effects of capture and handling stress on the animal must be taken into consideration when interpreting the data collected. The method used to sample the animals in this study included drive-netting for capture and physical restraint during sampling. Using these methods, deer have an extended period of strenuous activity which causes physiological changes. Increased respiration and heart rate are obvious effects of strenuous activity and increased temperatures can also be observed if an animal is unable to release the heat generated by the increased activity. Hematologic parameters such as red and white blood cell counts, hematocrit, hemoglobin, and plasma protein concentration can be altered with excitement and exercise and elevations in these parameters were observed in this study. Increased levels of muscle-derived enzymes such as creatine kinase (CK), aspartate aminotransferase (AST) can occur with vigorous exercise and this effect was observed in some of the deer sampled in this study as well.

Three of 11 adult females and four of six adult males captured during this study were judged to be in poor physical condition based on palpation of tail fat reserves. The remaining animals, including three juvenile females, were judged to be in fair condition. The lack of fat reserves, particularly in the three females, indicates that inadequate nutrition is available during the winter months. This undernutrition may affect reproductive rates but during normal years would not be expected to produce starvation induced mortality. However, at the current nutritional plane, mortality can be expected during periods of unusual winter stress such as was seen during 1996.

In contrast to the nutritional challenges of winter, the habitat following spring green-up appears to be more than adequate for maintenance and reproduction based on serum urea nitrogen, fecal nitrogen, fecal diaminopimelic acid (DAPA), and crude protein results. These tests provide an indication of forage quality and results were at or above high energy reference values for whitetailed deer. 
Six of nine adult does tested were pregnant based on serum progesterone results. Normally, close to $100 \%$ of adult does should be pregnant. Although the exact cause was not determined for these deer, lack of ovulation due to undernutrition is one possible cause for infertility in deer.

All 20 deer from this study had serum selenium values below the reference range and two of 12 animals tested had vitamin E levels that were deficient. Selenium-vitamin E deficiency causes a variety of problems in domestic ungulates including abortions, weak, stillborn or lethargic offspring, reduced fertility, delayed conception, reduced immune response, nutritional myopathy, or heart failure. Some researchers suggest that wildlife in selenium deficient ranges adapt to a certain extent and have lower selenium requirements than domestic animals. The mean selenium value for the 20 animals in this study was $39 \mathrm{ng} / \mathrm{ml}$ compared to a reference range of 100 to 180 $\mathrm{ng} / \mathrm{ml}$ reported for white-tailed deer (Puls, 1994). No pathologic lesions were seen in the captured deer that can be directly attributed to selenium-vitamin E deficiency although low serum selenium levels may be linked to the low productivity mentioned previously.

Fourteen of 18 deer had serum copper values below the reference range of 0.6 to $1.3 \mathrm{ppm}$ and six of these deer had serum copper levels $<0.05 \mathrm{ppm}$. Copper deficiency in cattle can cause abnormal hair quality, weight loss, anemia, delayed puberty, low conception and ovulation rates, and infertility. However, there doesn't appear to be a correlation between low serum copper and infertility in the deer from this study. Two does with a copper value $<0.05 \mathrm{ppm}$ were pregnant, one doe with a similar serum copper value was not, and one doe with a serum copper value within the normal range was not pregnant.

Based on virology, bacteriology, and serology, infectious diseases do not appear to be negatively impacting the population. No evidence of viral infection was seen from nasal swabs collected during capture and no significant bacteria were isolated from nasal or fecal swabs. There was serologic evidence of exposure to leptospira in seven of 20 deer sampled but clinical disease caused by this organism in white-tailed deer is rare and the results are not considered to be significant.

Parasitic eggs or larvae were identified from fecal samples of all 16 deer tested. Parasites of concern that were identified by fecal examination include lung worms ( 1 deer), strongyles, including the large stomach worm (Haemonchus contortus) (16 deer), and trematode eggs, most likely from liver flukes (Fascioloides magna) ( 2 deer). Another indication of parasite burden was observed in the serum chemistry and hematology results; sorbitol dehydrogenase (SDH) and eosinophil counts were both elevated (see below). These results do show that parasite burdens are affecting measurable parameters in the deer. Although the parasites identified and found at the levels listed above pose little threat to healthy deer herds, they are capable of causing deteriorated herd health and mortality, especially in fawns, in herds that exceed nutritional carrying capacity and are malnourished.

Clinical chemistry results identified elevated serum enzymes most commonly caused by muscle damage. Seventeen of 20 deer had elevated aspartate aminotransgerase (AST) values $($ mean $=329.5 \pm 425.7)$. One animal had an AST value of $2040.0 \mathrm{IU} / \mathrm{L}$. Creatine kinase $(\mathrm{CK})$ was elevated in seven deer. The animal with the AST of $2040.0 \mathrm{IU} / \mathrm{L}$ also had a CK value of $15490.0 \mathrm{U} / \mathrm{L}$. Muscle damage due to capture stress exacerbated by selenium deficiency is the most likely cause of elevated AST and CK levels. Deer captured for this study were not fitted with transmitters so it is unknown if capture myopathy related mortality occurred but clinical chemistry results indicate that at least one deer probably was affected by capture myopathy to an unknown extent. Elevated SDH levels, an indication of hepatic injury, were found in 19 of 20 deer. Hepatic damage caused by liver flukes is the most likely cause of aberrant SDH values. Liver flukes were found in nine of 10 deer necropsied in 1983, six of eight deer necropsied in 1996, and fluke eggs were found in fecal samples of two deer from this study. The percentage of deer from. this study infected with liver flukes was probably higher than $12.5 \%$ but low numbers of eggs in fecal samples are difficult to identify. 
Hematology results identified elevated WBC counts in 13 of 20 deer, primarily due to increased lymphocytes and eosinophils. Lymphocytes can increase with a physiological response to stress and excitement. Elevated eosinophils may reflect parasite burdens in the animal. The liver fluke was the most prominent parasite found in a past study of deer necropsied on Tenasillahe Island. Other slightly elevated hemotological values included the RBC count, HCT and plasma protein. A stress response from capture and handling can cause an increase in these values as well as dehydration which has been shown to accompany reduced feed intake and poor winter nutrition. The dehydration reduces the total blood volume and an increase in the components of the blood remaining in circulation is observed when compared to the total volume.

To reiterate, the major limiting factor for white-tailed deer on the Refuge appears to be seasonally deficient habitat and resulting undernutrition. Critical trace elements were also found to be deficient. If the carrying capacity is maintained at the current level, management objectives intended to increase the deer population on the refuge to promote delisting of the speciess maiy result in starvation related population declines during periods of unusual winter stress such as was seen in 1996. 


\section{3 \\ Materials and Methods}

Nine white-tailed deer ( 5 females, 1 male, 3 female fawns)from the mainland portion of the refuge, and 11 deer ( 6 females, 5 males) from Tenasillahe Island were captured during February 1998, by drive-netting with a helicopter. The drive net method for capturing deer entails hazing animals with a helicopter in an effort to chase them into a prepositioned $121 \mathrm{X} 2.7 \mathrm{~m}$ net ( $20.4 \mathrm{~cm}$ mesh) supported by spaced, paired, poles. These poles are erected in an A-frame configuration and are designed to topple when a running deer strikes the net. Animals that became entangled in the net were manually restrained during sampling.

In an effort to reduce capture stress, limits were placed on pursuit time for deer captures and handling time for sample collection. If helicopter pursuit for either drivenetting or net-gunning was not successful within 9 minutes of initiation, the pursuit was terminated (Sullivan et al., 1991). Handling time for sample collection was limited to approximately 5 minutes.

Deer captures were coordinated by refuge staff in conjunction with Washington Game and Fish, NWHC, and USDA personnel. During sampling, deer were blindfolded and efforts were made to control noise levels. Rectal temperature was monitored during sample collection and when body temperature exceeded $40.0^{\circ} \mathrm{C}\left(104^{\circ} \mathrm{F}\right)$ the deer were cooled with cold water. Each animal was given a cursory physical examination to screen for obvious parasites and lesions and to estimate physical condition by palpation of tail fat (Stockle et al., 1978). A veterinarian from the NWHC was on site to handle any physical or stress injuries that occurred during capture or handling. Trauma description and treatment was recorded on individual animal data sheets.

Body weight of captured deer was visually estimated. Age was estimated by tooth wear and replacement (Severinghaus, 1949) and assigned a category of fawn $(<21$ months), and adults (21 months, $>21$ months). Individual animal health, exposure to infectious diseases, and pregnancy rates were evaluated through the following protocol. A $35 \mathrm{ml}$ blood sample was collected from the jugular vein. Two $\mathrm{ml}$ of blood from each deer were stored in NaEDTA tubes for complete blood count (CBC) evaluation and measurement of plasma protein levels. Five $\mathrm{ml}$ of blood was collected in plastic nonrubber stoppered tubes for mineral analysis in order to adequately evaluate zinc levels. The remaining blood was stored in red top tubes and allowed to clot. Serum was harvested following centrifugation at $2,500 \mathrm{rpm}$ for 10 minutes. Serum was saved frozen and submitted for trace mineral analysis, vitamin E, serology (Wisconsin Animal Health 
Lab, Madison, Wisconsin), serum progesterone and serum chemistry (Animal Health Diagnostic Laboratory, East Lansing, Michigan) analyses. Whole blood samples in $\mathrm{K}_{3}$ EDTA were chilled and shipped overnight delivery to IDEXX Veterinary Services (Portland, Oregon) for hematological evaluation.

The serologic screen included testing for agents of bovine virus diarrhea (BVD), infectious bovine rhinotracheitis (IBR), Johne's disease, parainfluenza ${ }^{3}$ (PI3), bovine respiratory syncytial virus (BRSV), bluetongue (BT), epizootic hemorrhagic disease virus (EHD)strains 1 and 2, Anaplasma spp., Brucella ovis, B. abortus, and Leptospira interrogans serovars bratislava, canicola, grippotyphosa, hardjo, icterohaemorrhagiae and pomona. A fecal culture was taken for E. coli 0157:H7 and Salmonella spp. (NWHC, Madison, Wisconsin) analysis by swabbing the rectum. Additional fecal samples were collected from the rectum with a gloved hand for DAPA, fecal nitrogen, and crude protein analysis (Washington State University, Wildlife Habitat Laboratory) (Davitt and Nelson, 1984), and fecal parasite determination using the Sheather's flotation technique (NWHC). Two nasal swabs were collected from each deer, one for virus isolation for BVD, bovine coronavirus, IBR, bovine herpesvirus-2 (B.M.), bovine herpesvirus-4 (DN-599), bovine enterovirus (Dunne Groups 1-7), PI3, and respiratory syncytial virus (National Veterinary Services Laboratory, Ames, Iowa), and one swab for Pasteurella multocida culture (NWHC). 


\section{4}

\section{Results}

\section{Physical Condition}

Physical condition ratings based on palpation of tail fat reserves indicate that all deer were in fair or poor condition (Table 1). Eleven adult females were captured, eight of these animals were rated as being in fair condition and three were rated as poor. Two of five does from the mainland and one of six does from Tenasillahe Island were rated as being in poor condition. Of the six adult males captured, four were in poor condition (1 mainland, 3 Tenasillahee) and two males from Tenasillahee Island was in fair condition. Three fawns were captured on the mainland. All three animals were females in fair condition.

\section{Fecal DAPA, Fecal Nitrogen, and Crude Protein}

\section{Fecal DAPA}

Fecal DAPA analysis was conducted for fifteen deer ( 8 females, 5 males, 2 fawns) (Table 2 ). The remaining animals were not tested due to insufficient fecal samples. DAPA results ranged from 0.779 to $1.502 \mathrm{mg} / \mathrm{g}$ with a mean value and standard deviation (SD) of 1.186 and $0.224 \mathrm{mg} / \mathrm{g}$ respectively.

\section{Fecal Nitrogen}

Fecal nitrogen sampling was conducted for 7 deer ( 6 females, 1 male) (Table 2). Additional samples were not analyzed due to lack of sample material. Fecal nitrogen values ranged from 3.34 . $-3.98 \%($ mean $=3.64 \%, \mathrm{SD} \pm 0.25 \%)$.

\section{Crude Protein}

Fecal crude protein analysis was conducted for the same 7 deer tested for fecal nitrogen (Table 2). Crude protein values ranged from 20.85 to $24.84 \%$ (mean $=22.72 \%, S D \pm 1.59 \%$ ). 


\section{Serum Progesterone}

Nine of the 11 adult females captured during the study were evaluated for serum progesterone levels (Table 3). Reference values for pregnant and nonpregnant deer were $>1.8 \mathrm{ng} / \mathrm{ml}$ and $<0.85$ $\mathrm{ng} / \mathrm{ml}$ respectively (Wood et al., 1986). Six deer had serum progesterone values that suggest they were pregnant at the time of capture. These pregnant deer had a mean progesterone value of 4.35 $\mathrm{ng} / \mathrm{ml}$ (Range $3.46-6.29, \mathrm{SD} \pm 2.10$ ). Three deer had serum progesterone levels below the reference value that indicates pregnancy. Two of these deer had serum values of $0.31 \mathrm{ng} / \mathrm{ml}$. However, the third deer had an inconclusive result of $0.94 \mathrm{ng} / \mathrm{ml}$ that falls between the two reference values.

\section{Vitamin E and Selenium}

\section{Vitamin E}

Vitamin $\mathrm{E}$ levels were evaluated in serum from 12 of the 20 deer captured and ranged from 1.53 to $2.98 \mathrm{ug} / \mathrm{ml}$ (mean $=2.52, \mathrm{SD} \pm 0.33$ ) (Table 4). Seven of the 12 deer tested for Vitamin $\mathrm{E}$ were females and 5 were males. One female and 1 male had serum levels of vitamin $E$ lower than the reference range of 2.0 to $6.0 \mathrm{ug} / \mathrm{ml}$. The remaining animals had serum values within the reference range. Reference values for white-tailed deer are from the Animal Health Diagnostic Laboratory (Unpublished Data).

\section{Selenium}

All 20 deer captured during the study had serum selenium values lower than the white-tailed deer reference range of 100 to $180 \mathrm{ng} / \mathrm{ml}$ (Puls, 1994) (Table 4). The mean selenium value for all deer was $39 \mathrm{ng} / \mathrm{ml}$ (range 18 to $56, \mathrm{SD} \pm 12.7$ ).

\section{Mineral Levels}

Trace mineral analysis was conducted for 18 of the 20 animals captured during the study (Table 5). Deer numbers 12 and 15 were not tested due to insufficient serum volume. Whitetailed deer reference values for trace minerals are from Puls (1994).

Serum calcium levels were below normal for 8 of 10 females, 3 fawns, and 2 of the 5 males. Normal values ranged from $85-130 \mathrm{ppm}$. The mean serum calcium value for the deer in this study was 83.7 ppm (Range 77.4 - 91.4, SD \pm 3.8 ). All 18 deer had phosphorus values within the normal range of $44-90 \mathrm{ppm}$. Fourteen of the 18 deer tested had serum copper levels below the normal range of $0.6-1.3 \mathrm{ppm}$. Nine of 10 females and all five males had deficient serum copper levels. The mean value for all 18 animals was $0.3 \mathrm{ppm}$ (Range $<0.050-1.12, \mathrm{SD} \pm 0.4$ ). Serum zinc values were below normal for 12 of the 18 animals tested. Seven females, 3 males, and 2 fawns were below the normal range of $0.5-1.0 \mathrm{ppm}$. The mean serum zinc value for all 18 deer was $0.520 \mathrm{ppm}$ (range $0.344-0.926, \mathrm{SD} \pm 0.17$ ). The reference range for serum iron is $1.52-2.77$ ppm. Eight deer ( 5 females, 3 males) had serum iron values below the reference range. The mean for the animals in this study was $1.6 \mathrm{ppm}$ (Range 0.67-2.76, SD \pm 0.60 ). All 3 fawns had serum sodium results below the normal range of $3174-3450 \mathrm{ppm}$. The remaining deer had values within 
the normal range. The mean serum sodium value was 3222 ppm (Range 2960-3400, SD \pm 149 ). Serum magnesium was elevated in 12 of the 18 deer. Seven females, 2 males, and 3 fawns had serum magnesium values above the $18.0-26.0 \mathrm{ppm}$ normal range reported for elk. The mean serum magnesium value was $70.7 \mathrm{ppm}$ (Range 22.2 - 287, SD \pm 62.5 ). Five deer had serum potassium values above the normal range of $148-312 \mathrm{ppm}$. One female, 1 male, and 3 fawns had values higher than the normal range. The mean serum potassium value was 295 (Range 155-667, SD 162.9).

\section{Bacteriology, Virology, and Serology}

\section{Bacteriology}

Nasal swabs from 20 study deer were cultured for Pasteurella multocida. Pasteurella multocida was not isolated from any animal. Fecal swabs were submitted for Salmonella sp. and E. Coli 0157:H7 screening. All swabs were negative for Salmonella sp. and E. Coli 0157:H7.

\section{Virology}

No evidence of viral infection was observed in the inoculated bovine turbinate and vero cell cultures. Results were negative for BVD, bovine coronavirus, IBR, bovine herpesvirus- 2 (BHM), bovine herpesvirus-4 (DN-599), bovine enterovirus (Dunne Groups 1-7), parainfluenza ${ }^{3}$ (PI3), and respiratory syncytial virus.

\section{Serology}

Serum samples collected from all.20 deer were tested for neutralizing antibody titers for selected disease agents. Serum neutralization results for Anaplasma marginale, Mycobacterium paratuberculosis (Johne's disease agent), bluetongue virus, bovine respiratory syncytial virus, Brucella abortus, bovine viral diarrhea virus, epizootic hemorrhagic disease viruses types 1 and 2 , and infectious bovine rhinotracheitis virus were negative for all deer.

Seven deer had antibody titers to one or more Leptospira serovars (Table 6). One deer (014) had titers to three serovars, deer 013 and 020 had titers to two serovars, and four deer $(001,005$, 008, and 018) had titers to a single serovar. Leptospirosis screening was performed at an initial dilution of 1:100. Titers ranged from 1:100 to 1:3200.

\section{Parasitology}

Fecal samples for parasitology were collected from 16 ( 9 females, 5 males, 2 fawns) of the 20 deer captured. Results of the species and numbers of parasite eggs or larvae found are given in Table 7. Strongyloides sp. eggs were seen in 5 deer ( 1 female, 1 fawn, 3 males). The number of eggs seen per deer ranged from 1 to 4 with a mean of 1.6. Strongyle eggs were seen in all 16 animals tested. The number of eggs seen per deer ranged from 1 to 91 with a mean of 19.75 . Larval stage 1 Parelaphostrongylus sp. were found in fecal samples from 4 females and 1 male. The number of larva found per deer ranged from 1 to 10 with a mean of 3.6 . One female deer had 16 Larval stage 1 Dictyocaulus sp. in the feces. Dictyocaulus sp. larva were not seen in the other 
animals. Five deer ( 2 females, 2 males, 1 fawn) had Trichuris sp. eggs in the feces. The mean number of Trichuris sp. eggs per deer was 2.6 (Range 1-8). One Capillaria sp. egg was found in fawn 09. No eggs were found in the remaining deer. Unsporulated Eimeria sp. eggs were found in the feces of 1 fawn and 1 male; the fawn had $1 \mathrm{egg}$ and the male had 2 eggs. Trematode eggs were found in the feces of 1 female and 1 male deer. The female deer had 1 egg while 2 eggs were found in the male.

\section{Serum Chemistry}

A serum chemistry panel evaluating up to 25 blood parameters was conducted for all 20 deer captured uiuing the study (Table 8). Reference values for white-tailed deer are from Seal et al. (1981). Bovine reference ranges (Smith, 1996) were used when deer values were unavailable.

Sodium (Na) values were elevated in six deer (4females, 2 males) when compared to reference values that range from 132 to $156 \mathrm{mmol} / \mathrm{L}$. One deer (\#05) was not tested due to insufficient serum volume. The mean Na value for all 19 deer was 153.2 (Range 139.6-175.3, $\mathrm{SD}+36.6)$. Potassium $(\mathrm{K})$ values were elevated in 15 of the 18 animals tested. The mean $\mathrm{K}$ value (mmol/L) was 8.18 (Range 4.46-20.85, SD \pm 5.66 ) compared to the reference value range of 3.4 to 5.0. Animals with elevated $\mathrm{K}$ values included 8 females, 4 males, and 3 fawns.

Fourteen of 18 deer tested had chloride $(\mathrm{Cl})$ values greater than the reference range of 100 to 110 mmoi/L. Nine females and 4 males and 1 fawn had elevated $\mathrm{Cl}$ levels. The mean for all 18 deer was 114.3 (Range 108.3-128.6, SD \pm 5.7). Total CO2 (TCO2) levels were below the bovine reference range of 20 to $30(\mathrm{mmol} / \mathrm{L})$ for 14 of the 20 study animals. Eleven of the 14 deer with depressed TCO2 levels were females, the remaining 3 deer were males. The mean TCO2 value was 16.2 (Range 7.2-23.2, $\mathrm{SD} \pm 5.0$ ). Bovine reference values for anion gap ranged from 10 to $20 \mathrm{mmol} / \mathrm{L}$. All 18 deer from the study group had elevated values (Mean = 31.5, Range 22-45, $\mathrm{SD} \pm 7.4)$. The sodium/potassium ratio was calculated for 18 of the 20 deer. The mean ratio was 22 (Range 7-35, SD \pm ) compared to the reference ratio of 25-34. Nine deer had sodium/potassium ratios below the bovine reference range and two deer had slightly elevated values. Thirteen of 20 deer had elevated total protein (TP) values when compared to a reference range of 5.0 to $7.8 \mathrm{~g} / \mathrm{dl}$. Eight females, 4 males, and 1 fawn had TP values above the reference range. The mean TP value for all 20 deer was 8.2 (Range 7.3-10.1, $\mathrm{SD} \pm 0.7$ ). The mean albumin (g/dl) value for the 20 study animals was 3.3 (Range 2.6-3.9, $\mathrm{SD} \pm 0.4$ ). All deer tested were within the albumin reference range of 2.5 to 4.2 . Three female deer and 1 fawn had globulin ( $\mathrm{g} / \mathrm{dl}$ ) values higher than the bovine reference range of 2.6 to 5.4. The mean globulin value for all 20 deer was 4.9 (Range 3.8-6.3, $\mathrm{SD} \pm 0.6$ ). The albumin/globulin (A/G) ratio for white-tailed deer normally ranges from 0.6 to 1.2 . Four females, 1 male, and 1 fawn deer had $\mathrm{A} / \mathrm{G}$ ratios less than the reference range. The mean $\mathrm{A} / \mathrm{G}$ ratio for all 20 deer was 0.66 (Range $0.53-1.05, \mathrm{SD} \pm 0.21$ ). One female deer had a bilirubin value of $1.2 \mathrm{mg} / \mathrm{dl}$ compared to a reference range of 0.1 to 1.0 . The other 19 deer had values within the normal range. The mean value for all animals was 0.3 (Range $<0.1-1.2, \mathrm{SD} \pm 0.2$ ). Six deer ( 3 females, 3 males) had creatinine values above the reference range of 0.4 to $2.0 \mathrm{mg} / \mathrm{dl}$. The mean creatinine value for all 20 deer was 1.9 (range 1.4-2.4, $\mathrm{SD} \pm 0.3$ ). Alkaline phosphatase results were within the normal bovine reference range of 27 to $107 \mathrm{IU} / \mathrm{L}$ for 14 of 19 deer. Three animals had elevated alkaline phosphatase values while two deer had levels below the bovine reference value. The mean value was 81 (Range 20-186, SD \pm 39.7 ). The white-tailed deer reference range for aspartate aminotransferase (AST) is 40 to $150 \mathrm{IU} / \mathrm{L}$. Seventeen deer ( 9 females, 5 males, 3 fawns) had AST values above this range. The mean AST value was 330 (Range 120-2040, SD \pm 
426). Calcium values were above the reference range of 8.8 to $10.8 \mathrm{mg} / \mathrm{dl}$ for 7 deer ( $4 \mathrm{females,}$ 3 males), and below the reference range for 1 female. The mean calcium value was 10.4 (Range 8.6-12.1, $\mathrm{SD} \pm 0.9$ ). All 20 deer had cholesterol values within the reference range of 30 to 100 $\mathrm{mg} / \mathrm{dl}$ with a mean of 50 (Range 39 to $60, \mathrm{SD} \pm 5$ ). Creatine kinase levels were elevated in seven deer ( 2 females, 2 males, 3 fawns) when compared to the reference values of 20 to $400 \mathrm{U} / \mathrm{L}$. The mean value for all 20 deer was 1161 (Range 150-15490, SD \pm 3468 ). Twelve of 20 deer had elevated gamma glutamyl transferase (GGT) values and one deer had a value below the reference range of 40 to $100 \mathrm{U} / \mathrm{L}$. Seven females, 3 males and 2 fawns had elevated GGT values, and one female had a depressed GGT value. The mean GGT value for all 20 deer was 172 (Range 23$735, \mathrm{SD} \pm 175$ ). Glucose values were within the reference range of 60 to $320 \mathrm{mg} / \mathrm{dl}$ for all 20 deer. The mean value for all deer was 128 (Range 69-221, SD \pm 35 ). All 20 deer had magnesium $(\mathrm{Mg})$ values above the bovine reference range of 1.8 to $2.3 \mathrm{mEqL}$. Elevated $\mathrm{Mg}$ results ranged from 2.45 to 14.30 (Mean $=7.29, \mathrm{SD} \pm 3.45$ ). Phosphorus $(\mathrm{P})$ results were depressed in 3 of 20 deer ( 2 females, 1 fawn) when compared to a reference range of 4.5 to 8.5 $\mathrm{mg} / \mathrm{dl}$. The mean $\mathrm{P}$ value for all deer was 5.7 (Range 2.9-8.2, $\mathrm{SD} \pm 1.2$ ). All 20 deer had serum urea nitrogen (SUN) results within the reference range of 15 to $45 \mathrm{mg} / \mathrm{dl}$. Serum urea nitrogen values ranged from 28 to 39 (Mean $=33, S D \pm 3$ ). Bovine reference values for sorbitol dehydrogenase $(\mathrm{SDH})$ range from 12 to $53 \mathrm{U} / \mathrm{L}$. Nineteen of 20 study animals had SDH values above the reference values with a mean of 110.4 (Range 15.3 to $211.0, \mathrm{SD} \pm 47.0$ ). Osmolality $(\mathrm{mOs} / \mathrm{kg}$ ) was reported for 18 deer. Fifteen deer ( 8 females, 6 males, 1 fawn) had values above the bovine reference range of 270 to 300 . Tested animals had a mean value of 325 (Range 295$368, \mathrm{SD} \pm 21.3$ ). Results of iron ( $\mathrm{Fe})$ analysis indicate that 3 females of 20 deer tested had serum Fe values greater than the reference range of 70 to $225 \mathrm{ug} / \mathrm{dl}$ and 1 female had serum $\mathrm{Fe}$ lower than this range. The mean Fe value was 158 (Range $67-261, \mathrm{SD} \pm 56$ ).

\section{Hematology}

Blood parameters were examined in all 20 deer and included a hematocrit (HCT), white blood cell count (WBC), red blood cell count (RBC), hemoglobin (HGB), mean corpuscular volume (MCV), mean corpuscular hemoglobin concentration (MCHC), mean corpuscular hemoglobin $(\mathrm{MCH})$, a differential white blood cell count based on a blood smear using blood from the EDTA tube, evaluation of platelets and red blood cell morphology, and plasma protein.

Calculations were also made from the differential WBC to determine absolute numbers of neutrophils, lymphocytes, monocytes, eosinophils and basophils (Table 9). Normal values for white-tailed deer hematology are from Seal et al. (1981).

Red blood cell counts (RBC - Millions/uL) were elevated in 5 deer ( 3 females and 2 fawns) compared to the normal range of 10.0-16.7. The mean RBC count was 15.4 (Range 11.5-18.5). Hemoglobin $(\mathrm{g} / \mathrm{dl})$ values were within the normal range of 14.5-22.5 for all but 1 deer. Hematocrit (HCT - \%) values were elevated in 8 deer ( 5 females, 2 fawns, 1 male) when compared to a normal range of 39-58. The mean HCT value was 56.9 (Range 42.2-65.4, SD 5.7). Nine deer ( 5 females, 4 males) had elevated mean corpuscular volume (MCV-fL). The normal range for MCV is 28-38 compared to a mean of 37.4 (Range 30-42, SD 3.2) for the study animals. Mean corpuscular hemoglobin $(\mathrm{g} / \mathrm{dl})$ values were within the normal range of 7-15 for all deer. Eighteen of 20 deer had mean corpuscular hemoglobin concentrations (PG) less than the normal range of 34-40. The average $\mathrm{MCHC}$ was 33.0 (Range 30.6-34.5, SD 0.9). The two normal animals included one female and one fawn. 
White blood cell counts (WBC-Thousands/uL) were above the normal reference values for 13 of 20 deer (6 females, 5 males, 2 fawns). The mean WBC count was 5.0 (Range 2.6-6.6, SD

1.5) compared to a normal range of 1.0-4.2. The WBC differential looks at the different types of WBCs that make up the count by evaluating 100 WBCs cells on a blood smear. These counts are expressed in percentages and represent the number of each cell type counted in the differential. The absolute cell count $(/ \mathrm{uL})$ is a calculation based on this percentage and the total number of WBC in the sample. Neutrophil counts (\%) were below the normal range (57-72) for 19 of the 20 deer but within the normal range of absolute counts (600-2800) with the exception of 1 female and 1 male with higher than normal values and 1 female with lower than normal absolute values. Lymphocyte counts (\%) were above the normal range (24-35) for 10 deer and below the normal range for 1 deer. Ten of the 20 deer ( 5 females, 4 males, 1 fawn) had absolute lymphocyte values above the normal range (600-1800). Seven of the deer with elevated lymphocyte values were females, 3 were males, and the 1 animal with a value below the normal range was a female. Sixteen deer had monocyte (\%) counts higher than the normal range (1-3) and 1 deer (006) had no monocytes observed in the differential. All but 1 deer (006) had absolute monocyte counts higher than the reference value of $<10.0$. Eosinophil (\%) values were above the normal range of 2-7 for all 20 deer and the mean was 22 (Range 12-41, SD 8). Absolute eosinophil (/uL) counts were higher for all 20 deer when compared with a normal range of $<100$. The mean absolute eosinophil value was 1135 (Range 260-3444, SD 694). Ten animals ( 6 females, 1 fawn, and 3 males) had basophils (\%) noted in the differential count (1-4). These animals had extremely elevated levels compared to the reference range of $<10$ (36-156). Platelet counts were reported as either increased, adequate, or decreased. Nineteen of 20 deer had adequate platelet counts. One deer $(020)$ had a decreased count. Poikilocytosis refers to abnormally shaped red blood cells. The levels were reported as either slight, moderate or marked. Poikilocytosis was slight in 7 deer ( 5 females, 1 male, 1 fawn), moderate in 10 deer ( 7 females, 2 males, 1 fawn), and marked in 1 deer (male, 017).

Plasma protein $(\mathrm{g} / \mathrm{dl})$ reference values normally range from $5.0-7: 8$. Seven deer (6 females, 1 male) had values higher than the reference values. The mean plasma protein value was 7.7 (Range 6.6-9.0, SD 0.7). 


\section{5}

\section{Discussion}

Physical condition ratings were estimated for each deer at the time of capture based on palpation of tail fat reserves. Fat reserves are, at best, hard to measure quantitatively and even techniques that involve direct examination of fat deposits are often no more than a subjective evaluation. Palpation of tail fat was meant to serve only as a rough criteria of the animal's physical condition and was used in conjunction with other indices in the evaluation of overall animal health.

Three of 12 females and four of five males were judged to be in poor physical condition based on lack of tail fat reserves, and the remaining deer were judged to be in only fair condition. Adult males normally enter the winter period in poorer physical condition than females due to the stresses encountered during the breeding season. During this period males can loose $20 \%$ of their body weight (Hoffman and Robinson, 1966). The poor condition of the four males in this study can be attributed at least in part to breeding stress, but the three adult does that lacked tail fat may be an indication of seasonally marginal habitat. There is a close relationship between maternal nutrition and neonatal mortality (Verme, 1962). Pregnant does on a good quality diet average $7 \%$ fawning loss while does on a low plane of nutrition have about $93 \%$ fawn mortality. The rate of stillbirths also increases among does on a low nutritional plane.

Fecal DAPA is a component of the cell walls of rumen bacteria which produce a large portion of the digestible energy of ruminant animals. DAPA passes through the herbivore digestive track undigested and its level in feces may reflect rumen bacterial population levels and indicate intake of digestible energy (Kucera, 1997). Therefore, fecal DAPA results are an indication of the energy content of forage ingested 24 to 48 hours prior to defecation. Fecal DAPA levels are usually around $0.30 \mathrm{mg} / \mathrm{gm}$ during the winter and at or above $1.00 \mathrm{mg} / \mathrm{gm}$ during spring and early summer when quality vegetation is available (B. Davitt, pers. comm.). In this study, fecal samples were collected directly from the captured animals. Results from 15 deer ranged from 0.78 to $1.50 \mathrm{mg} / \mathrm{gm}$ with a mean and standard deviation of 1.19 and $0.22 \mathrm{mg} / \mathrm{g}$ respectively. These results indicate that the deer sampled during this study were feeding on quality forage during the time of capture.

Fecal nitrogen (FN) is positively correlated with forage quality, dietary protein and digestibility (Leslie and Starkey, 1985), and tends to increase as dietary nitrogen increases thus providing an indication of dietary quality. Criticisms of FN as an index of dietary quality are based on the finding that secondary plant metabolites such as tannins in diets might influence FN levels (Mould and Robbins, 1981). Seasonal differences are seen in FN results with values being higher in spring and summer than in winter. Leslie et al. (1989) reported white-tailed deer FN results ranging from $1.24 \%$ in winter to $3.72 \%$ in summer. Values from seven deer tested for

this study ranged from 3.34 to $3.98 \%$ and reflect the increase in nutritional vegetation available during spring green-up. 
Fecal crude protein is an index designed to estimate ingested plant protein. Plant protein increases during early growth and can often be as high as $20-30 \%$, but subsequently falls to as little as 3-4\% at maturity (Robbins, 1993). Brown et al. (1995) reported fecal crude protein values ranging from $10.4 \%$ for a low protein-low energy diet to $14.6 \%$ for a medium proteinmedium energy diet. The mean fecal crude protein value for the seven deer tested during this study was $22.7 \%$ and as with fecal nitrogen, this high crude protein value is an indication of consumption of new plant growth.

Serum urea nitrogen (SUN) is a good indicator of recent protein intake (Brown et al., 1995). SUN values for the 20 study animals ranged from 28.0 to $39.0 \mathrm{mg} / \mathrm{dl}$ with a mean value of 33.4 $\mathrm{mg} / \mathrm{dl}$. The reference range for white-tailed deer reported by Seal et al. (1981) was 15 to 45 $\mathrm{mg} / \mathrm{dl}$. The SUN findings support the results of fecal nitrogen, fecal DAPA, and crude protein analysis all of which indicate that at the time of capture the study animals were consuming forage that had more than adequate protein for maintenance and fawning.

Lack of tail fat reserves indicate that the deer captured for this study had marginal nutritional resources during the winter months. In contrast, FN, crude protein, DAPA, and SUN results that measure the quality of forage ingested at the time of capture show that the habitat at spring green up is more than adequate for maintenance and reproduction.

Serum progesterone levels were used to determine pregnancy in nine of the does captured during the study (Table 2). Additional females were not sampled due to insufficient serum volume. Wood et al. (1986) concluded that serum progesterone values of $\geq 1.8 \mathrm{ng} / \mathrm{ml}$ were indicative of pregnancy. Plotka et al. (1983) questioned the reliability of conclusions drawn from a one time sample but Wood et al. (1986) found that single serum progesterone samples were reliable indicators of pregnancy. Six of nine adult does sampled for serum progesterone were judged to be pregnant and one doe had a serum progesterone result that was inconclusive. Mean serum progesterone values for pregnant and nonpregnant does were 4.45 and $0.52 \mathrm{ng} / \mathrm{ml}$ respectively. All does tested for serum progesterone levels were $>21$ months old. Normally close to $100 \%$ of the does $>21$ months old would be pregnant if adequate nutrition is present. Two does were judged to be not pregnant at the time of capture and the exact cause cannot be determined. However, nonfertilization or embryonic mortality rarely can be attributed to nutritional deprivation because does are in their best physical condition during the fall breeding season (Verme and Ullrey, 1984), and even when acutely malnourished, does rarely abort (Verme, 1962), although, as previously mentioned selenium deficiencies can cause abortions. Protein deficiency is commonly considered a limiting factor in deer productivity although as little a $7 \%$ protein intake is sufficient for normal reproduction (Murphy and Coates, 1966). The productivity of white-tailed does fed a good ration in autumn was nearly twice that of those on restricted diets (Verme, 1965) and fawning rates almost tripled when does were switched from low to high nutrition in autumn trials (Verme, 1967). Nutrition apparently affects ovarian development by regulating the rate at which follicle stimulating hormone is released by the pituitary and on submarginal ranges it is not uncommon for 1.5-year-old does to remain sexually immature (Verme and Ullrey, 1984).

Dietary selenium, a trace element, and vitamin $\mathrm{E}$ act synergistically as antioxidants to maintain the functional integrity of cellular and subcellular membranes (Blood et al., 1983). Selenium-vitamin E deficiencies in domestic animals cause increases in AST, CPK, and LDH, retained placentas, abortions, weak, stillborn or lethargic offspring, reduced fertility, delayed conception, erratic estrous periods, reduced immune response and associated pneumonia, foot rot, scouring, mastitis, and in severe cases, nutritional myopathy, or terminal heart failure. Mountain goats (Oreamnos americanus) with low blood selenium levels were very susceptible to capture myopathy (Robbins et al., 1985). Brady et al. (1978) questioned why domestic livestock from selenium deficient areas developed clinical signs or died while deer from the same areas 
survived without apparent problem. They concluded that dietary selenium requirements of white-tailed deer are low when compared to those of domestic animals. All 20 deer captured during this study had serum selenium values below the white-tailed deer reference range of 100$180 \mathrm{ng} / \mathrm{ml}$. Portions of the Pacific northwest, including the study area, have low selenium concentrations in plants. Approximately $80 \%$ of all forage and grain in these areas contain $<0.05$ ppm of selenium (Robbins, 1993). However, Brady et al. (1978) found that white-tailed deer consuming a diet of $0.04 \mathrm{ppm}$ selenium were not pathologically deficient. Vitamin $\mathrm{E}$ levels were evaluated for 12 of the 20 deer captured. Two deer (one female, one male) had vitamin $\mathrm{E}$ values lower than the reference range of $2.0-6.0 \mathrm{ug} / \mathrm{ml}$ (Table 3). These two deer had deficiencies of both selenium and vitamin E but did not have AST or CK values indicative of capture or nutritional myopathy. The study animals from the refuge were not examined in sufficient detail to identify pathologic problems associated with selenium-vitamin E deficiency. However, the possibility that selenium-vitamin E deficiencies are affecting the population through reduced reproduction, fawn survival or adult morbidity cannot be ruled out. Cattle producers in selenium deficient areas commonly provide selenized salt or mineral blocks containing 25-125 ppm Se to their livestock (Puls, 1988), and it has been suggested that wildlife capture programs in selenium deficient areas begin selenium supplementation (free choice salt blocks) at least one month prior to capture attempts (Robbins et al.,1985).

Of the eighteen deer tested for trace mineral analysis (Table 4), thirteen deer, 10 does, 2 fawns, and 1 male, had serum calcium results below the reference range of $85-130 \mathrm{ppm}$. Calcium in herbage occurs as oxalate crystals, which are less soluble than calcium salts. The ability to absorb calcium ingested as oxalates is dependent on bacterial fermentation and adaption of the rumen bacteria through previous exposure (Robbins, 1993). Thus, seasonal microbial adaptation is required for proper utilization of ingesta (Verm and Ullrey, 1984). The animals captured during this study had loose feces indicating a change in diet to newly sprouted green vegetation. This seasonal change in diet may affect calcium levels because a lag in microbial adaptation to the new food source may make calcium absorption less efficient.

Serum copper results were below the reference range of $0.6-1.3 \mathrm{ppm}$ for 14 deer. Six deer (5 females, 1 male) had serum copper values $<0.05 \mathrm{ppm}$. Copper deficiencies in wild ruminants have occurred world-wide and are common in severely leached or alkaline soils although species that exist in low copper areas adapt to a certain extent (Robbins, 1993). Symptoms include pale, faded, brittle pelage, abnormal hoof and antler growth, weight loss, anemia, ataxia, poor immune function, and reduced reproduction. In addition, neonatal ataxia caused by copper deficiencies may make fawns more prone to predation. However, there doesn't appear to be a correlation between low serum copper and infertility in the deer from this study. One doe with a copper value $<0.05 \mathrm{ppm}$ was pregnant, one deer with a similar serum copper value was not, and one animal with a serum copper value within the normal range was not pregnant. No clinical signs were seen in the captured animals that were directly attributable to copper deficiency.

Serum zinc values were depressed in 12 of 18 deer sampled when compared to a reference range of $0.5-1.0 \mathrm{ppm}$. Clinical signs of zinc deficiency include reduced growth and feed intake, decreased efficiency of food utilization, impaired growth, and dermatitis. Deficient results from this study ranged from $0.344-0.682 \mathrm{ppm}$ and five deer had serum zinc values that were reduced approximately $50 \%$ below the reference values. Robbins (1993) states that zinc deficiencies have not been reported in wild animals.

Magnesium values were elevated in 12 deer when compared to bovine normal values of 18.0-26.0 ppm. Elevated serum $\mathrm{Mg}$ values ranged from 51.6-287.0 ppm. Interestingly, hypermagnesemia was seen in all 10 of the deer from the mainland and only two animals from Tenasillahe Island. Hypocalcemia and hypermagnesemia correspond in 11 of the 12 deer with increased $\mathrm{Mg}$ values. 
Serum potassium results were elevated for 5 of the 18 deer sampled. Five of these deer had potassium values more than double the reference values of 148-312 ppm. Potassium excesses have been reported in horses after vigorous short-term exercise usually associated with a lactic acidosis or anaerobic workload (Smith, 1996). Hyperkalemia can also occur after a blood sample has been taken with red blood cell destruction causing hemolysis of the serum or when with the release of potassium from WBC or platelets after blood has clotted in a tube. Otherwise, it occurs relatively rarely and are generally associated with an alteration in renal excretion of potassium (Carlson, 1989). Assessment of serum potassium values requires a knowledge of probable intake and sources of excessive loss as well as the status of renal function and acid-base balance (Carlson, 1989).

Serologic titers to leptospirosis were seen in seven of the 20 deer captured (Table 5). Leptospirosis is caused by the spirochete Leptospira interrogans of which there are more than 180 serovarieties (serovars). Serum samples were tested for the six most common serovars found in white-tailed deer. Titers to four serovars were seen during this study and included bratislava, grippotyphosa, hardjo, and pomona. Leptospirosis can infect a wide variety of species but white-tailed deer are not considered a reservoir of the disease (Shotts, 1981). The frequency with which various serovars have been associated with a certain species have implicated those animals as hosts of the disease. Host species include swine and horses (bratislava), raccoons (grippotyphosa), and cattle (hardjo and pomona) (Shotts, 1981).

Serologic surveys have been conducted to determined the prevalence of leptospirosis in white-tailed deer. In Illinois and Minnesota $16 \%$ of the white-tailed deer had antibody titers to L. pomona, and 26\% had similar titers in Wisconsin (Roth, 1970; Trainer et al., 1963). Seven serovars were seen, and $9.5 \%$ of 369 deer had titers to leptospirosis in Nebraska (Shotts, 1981). Naturally occurring clinical leptospirosis in white-tailed deer is rare, but a few cases involving serovar pomona have been reported (Davidson and Nettles, 1997). Clinical signs from experimental infections with $L$. pomona in white-tailed deer range from mild disease to death. However, white-tailed deer do not serve as long term carriers.

During this study leptospira titers ranged from 1:100 to 1:3200 but no indication of clinical leptospirosis was seen. Interpretation of serologic results is normally based on paired serum samples collected 2-4 weeks apart. In this study we have only a one time sample. Thus, many of the positive results may just indicate previous exposure to the disease and not active infection.

Threadworm eggs of the genus Strongyloides were found in low numbers in five deer (Table 6). Threadworms are relatively uncommon in white-tailed deer and due to their scarcity and low prevalence of infection usually pose no problem to free-ranging deer. However, mortality due to Strongyloides sp. can be particularly severe in confined deer (Prestwood and Pursglove, 1981).

Strongyle eggs were seen in the fecal samples of all 16 deer tested during this study. Foreyt (1983, unpubl. data) found strongyles in the abomasums of nine of 10 deer necropsied, but no strongyle eggs in fecal samples from 40 deer tested in 1995 (Foreyt, 1995, unpubl. data). Most helminths found in the gastrointestinal tract of white-tailed deer belong to the family Trichostrongyloidea and include nematodes of the genera Haemonchus, Apteragia, Ostertagia, Trichostrongylus, Nematodirus, and Cooperia (Prestwood and Pursglove, 1981). Eggs from these genera are lumped under the heading of Strongyle eggs because exact speciation is not possible. The large stomach worm Haemonchus contortus is widely distributed among whitetailed deer and is capable of causing mortality, particularly in fawns in substandard habitats (Prestwood and Pursglove, 1981). The normal clinical signs of haemonchosis include blanching of the mucous membranes and ears due to blood loss, stunting, and emaciation. Hemoglobin, hematocrit, and total serum protein values may also be depressed. The two fawns captured during this study had the highest number of strongyle eggs in the fecal samples. However, the previously mentioned clinical signs were not seen in either deer. Hemoglobin and plasma 
protein values were normal when compared to values found in 6 month old white-tailed deer (Seal et al., 1981), and hematocrit values were actually slightly elevated. The inability to speciate the eggs coupled with the small sample size confound interpretation of these data. Annual monitoring of fawn survival would be required to determine if this parasite is having an effect on the population. The medium stomach worms of the genera Apteragia and Ostertagia are the most commonly encountered abomasal helminths of deer (Prestwood and Pursglove, 1981). Studies of white-tailed deer from 14 southern states and the Virgin Islands found medium stomach worms in all but 15 of 939 deer. Clinical signs have not been seen associated with medium stomach worms although the presence of large numbers of worms may be an indication of other diseases, debilitation, or malnutrition.

Hairworms, Trichostrongylus spp., are the least common abomasal helminths of white-tailed deer. No clinical signs have been associated with low numbers of Trichostrongylus in deer. The low incidence and prevalence of Trichostrongylus and the iaci of clinical signs makes this species of little importance in the health of white-tailed deer (Prestwood and Pursglove, 1981). Thread-necked strongyles, Nematodirus odocoilei, are only occasionally encountered in both white-tailed and black-tailed deer. The significance of $N$. odocoilei in white-tailed deer health is minimal. Even in deer heavily infected with the parasite no pathogenicity was seen. Several species of the intestinal nematode Cooperia have been reported in white-tailed deer. However, the numbers of nematodes found in deer are usually small and pathogenicity is not associated with the infections.

Fecal samples from five deer contained first stage larva of the nematode Parelaphostrongylus sp. In white-tailed deer this genus contains the species $P$. tenuis and $P$. andersoni, while $P$. odocoile $i$ is found in mule deer (O. hemionus) and black-tailed deer $(O$. columbianus). The eggs and larva of $P$. tenuis and $\mathrm{P}$. andersoni cannot be distinguished morphologically (Anderson and Prestwood, 1981), and white-tailed deer are refractory to $P$. odocoile $i$ and consequently do not shed larvae in the feces (Platt and Samuel, 1978). The meningeal worm $(P$. tenuis) has not been reported in the Pacific northwest and post mortem examinations of eight deer in 1996 did not reveal the parasite. Therefore, the larvae found in the fecal samples were most likely from the muscleworm $P$. andersoni. White-tailed deer tolerate moderate muscle worm infections well, but disturbances in posture and gait were seen in experimental deer given massive numbers of $P$. andersoni (Anderson and Prestwood, 1981). No attempts were made to locate this parasite during the post mortem examinations conducted in 1996 (Glaser and Creekmore, 1996, unpubl. data).

Trichuris, or whipworm, is a nematode found in the cecum of domestic animals and wild ruminants. Fecal samples from five of the 16 deer contained whipworm eggs. In comparison, Foreyt found Trichuris eggs in five of 40 deer tested in 1995. Infected white-tailed deer normally harbor only small numbers of Trichuris and no pathological changes have been attributed to the parasite (Bergstrom and Honness, 1982). As a result, trichuriasis likely poses little or no threat to the health of white-tailed deer.

Capillaria spp. are present on every continent and infect hosts ranging from fish to mammals (Honness, 1982). A single Capillaria egg was found in the feces from one deer captured on the refuge and Foreyt (1995, unpubl. data) found Capillaria eggs in two of 40 deer tested. There are no known clinical signs or pathologic changes attributable to Capillaria and this parasite is of little importance to all known hosts.

Coccidia of the genus Eimeria infect a wide variety of hosts including wild ruminants (Kingston, 1981). Two deer had unsporulated oocysts in fecal samples collected during the study while five of 40 animals were positive in 1995 (Foyet, 1995, unpubl. data). No clinical signs have been found in naturally infected white-tailed deer but mule deer (O. hemionus) fawns experimentally infected with $E$. mccordocki developed diarrhea. Health problems due to Eimeria 
are probably minimal and any problems would most likely occur only in fawns.

Trematode eggs were found in the feces of two deer captured during the study. Based on past findings, the most likely source of the fluke eggs is the Large American liver fluke . $F$. magna were found in six of eight deer during post mortem examinations conducted following the flood event of 1996 (Glaser and Creekmore, 1996, unpubl. data) while Foreyt (unpubl. data) found liver flukes in nine of ten adult deer necropsied in 1983 and fluke eggs in 32 of 40 samples from 1995. White-tailed deer usually tolerate liver flukes without exhibiting clinical signs (Foreyt, 1981), and morbidity or death usually occurs only in fawns. However, heavy burdens of liver flukes or other parasites may exacerbate conditions of malnutrition or other disease.

Clinical chemistry deals with the interpretation of clinical laboratory data in an attempt to identify deviations from normal values. Normal values or reference ranges are used as comparisons for test values. However, sources of variation in normal values include factors unrelated to disease processes. Sample handling, animal handling, variations in laboratory analysis, species differences, age, and sex are some of the variables that affect test results (Carlson, 1996). Therefore, minor deviations from the reference range are not necessarily an indication of an underlying disease problem. Results were within the normal range for all animals in only five of the 25 tests conducted (Table 7). The number of deer with results above or below the reference values ranged from one (bilirubin) to all deer sampled (anion). Most tests had results from several animals that were not within the normal range. However, with the exception of $\mathrm{K}, \mathrm{Mg}, \mathrm{AST}, \mathrm{CK}$, and $\mathrm{SDH}$ these aberrant values are only slightly outside the reference ranges and are not considered to be indicators of disease.

Potassium values were elevated in 15 of the 18 deer tested when compared to the whitetailed deer reference range of 3.4-5.0 $\mathrm{mmol} / \mathrm{L}$. Causes of hyperkalemia in domestic animals include acidosis, intracellular to extracellular movement of K (Tasker, 1980), serum hemolysis, delays in serum harvest, and renal disease. No correlations were seen between serum $\mathrm{K}$ values and stress indicators such as body temperature, AST, or CK, and no relationship was found between sample handling and serum $\mathrm{K}$ results. Tasker (1980) reported that the principle danger of hyperkalemia is cardiac arrest and that electrocardiographic abnormalities occur when serum potassium reaches $7 \mathrm{mmol} / \mathrm{L}$ and death usually occurs when serum $\mathrm{K}$ values reach $10-12$ MMOL/L. Two deer had serum $\mathrm{K}$ values greater than $7 \mathrm{mmol} / \mathrm{L}$ (7.37 and 7.02) while six deer had serum K values that ranged from 12.5 to $20.9 \mathrm{mmol} / \mathrm{L}$. Normal serum $\mathrm{K}$ values for whitetailed deer reported by Seal (1981) were 3.4-5.0 mmol/L and these values are simular to the bovine reference range of 4.1-5.1 mmol/L (Puls, 1988). However, DelGiudice et al. (1992) found seasonal variation in serum $\mathrm{K}$ among deer from Minnesota. Mean serum $\mathrm{K}$ values ranged from a high of $10.0 \mathrm{mmol} / \mathrm{L}$ in January to a low of 4.5 during July and September. Elevated serum $\mathrm{K}$ values (9.5-11.2) were also reported in Oklahoma during spring and summer (DeLiberto et al., 1989). DelGiudice et al. (1992) attributed winter hyperkalemia to an endogenous rhythm related partial renal shutdown associated with reduced circulatory fluid or decreased plasma volume. In Colorado, serum $\mathrm{K}$ levels in mule deer were highest in spring and summer, when the potassium content of plants was highest (Anderson et al., 1972). No relationship was found between sample handling and serum $\mathrm{K}$ results and no conclusions can be made between serum $K$ values and nutritional indices such as crude protein, fecal nitrogen, and fecal DAPA because only one of six deer with the highest serum $\mathrm{K}$ results had sufficient fecal material to perform the above tests. Samples were collected, handled, and stored the same for both locations and the weather conditions were similar between sampling days. The cause of the variation in serum $\mathrm{K}$ results between the mainland deer and animals from Tenasillahe Island remains unknown. Additional sampling would be required to determine if the serum $\mathrm{K}$ difference between populations was caused by procedural variation or is indeed a physiological 
difference.

Magnesium is an essential component of bones and teeth and is important in enzyme activation in energy metabolism. Values were elevated for 17 deer and amounted to almost a 5 fold increase above the bovine reference values for two animals. The use of bovine reference values may not correlate to white-tailed deer normal levels, however these values exceed typical variations between ruminant species. No relationship was seen between serum $\mathrm{K}$, pregnancy, or serum hemolysis, and elevated $\mathrm{Mg}$ levels. Adrenal and renal insufficiency also causes hypermagnesemia and the elevated $\mathrm{Mg}$ result may be linked to the seasonal renal shutdown discussed in the previous paragraph. There is also a reciprocal relationship between $\mathrm{Mg}$ and $\mathrm{Ca}$ and in oxalate poisoning. A decrease in serum calcium is accompanied by an increase in serum $\mathrm{Mg}$. However, serum Ca values for these deer were unremarkable and the cause of increased serum magnesium values remains unknown.

Aspartate aminotransferase is an enzyme found in a variety of tissues and increases of this enzyme in the circulation indicate nonspecific tissue damage, usually to skeletal muscle or liver tissue. Elevations of AST associated with muscle damage have been reported in white muscle disease of domestic animals (Ruth and Van Vleet, 1974), tying up and paralytic myoglobinuria in horses (Equis cabilis) (Cornelius and et. al, 1963), and capture myopathy in moose (Alces alces) (Haigh et al., 1977) and pronghorns (Antilocapra americana) (Chalmer and Barrett, 1977). Other causes of elevated AST include selenium deficiency and liver damage caused by liver flukes (Carlson, 1996). Sample collection and handling also affects AST results. Hemolysis of serum tested for AST can cause a $220.0 \%$ increase in the result (Statland and Winkel, 1979), although it does not appear to be a contributing factor here. Four animals with the highest AST values ( $>400 \mathrm{IU} / \mathrm{L}$ ) had serum samples with no or slight hemolysis. Two deer with the moderate hemolysis of serum had lower values of 123 and $174 \mathrm{IU} / \mathrm{L}$ respectively. Although rectal temperatures only provide a general indication of stress in captured deer, three deer had rectal temperatures of $104^{\circ} \mathrm{F}$. These deer had AST values of 405, 403, and 468 respectively. The deer with the AST value of 2040 had a rectal temperature of 102.8 and one animal with a rectal temperature of $103.8 \mathrm{had}$ an AST of $120 \mathrm{IU} / \mathrm{L}$. The normal range for AST in white-tailed deer is 40 to $150 \mathrm{IU} / \mathrm{L}$. Only three deer had values within this range. More importantly, six deer had values more than twice the normal range with one deer having an AST value of $2040 \mathrm{IU} / \mathrm{L}$. The mean value for all deer was 329.5. Capture stress, selenium deficiency, liver flukes and serum hemoloysis may all contribute to the elevated AST values in these animals.

Creatine kinase (CK) is an enzyme found in skeletal muscle and is a sensitive indicator of muscle damage in domestic animals. Causes of elevated CK in the circulation are related to muscle exertion and enzyme levels can increase 4-fold with vigorous exercise (Smith, 1996) with more dramatic increases ocurring with severe muscle damage. $\mathrm{CK}$ results were above the normal range of 20-400 U/L in seven deer. All but deer \#16 had modest increases within the 4fold range attributable to vigorous exercise. Deer \#16 had a much higher level of CK indicating more severe muscle damage.

Six of seven animals with modestly elevated CK had elevated AST and one animal had markedly elevated CK and AST (Deer \#16). These animals likely experienced muscle exertion to varying degrees during capture and handling. This effect may have been exacerbated by selenium deficiency and/or liver flukes. All animals had lower selenium than the normal ranged reported for white-tailed deer, and based on previous data (Glaser, Creekmore, 1996, unpubl.data), the majority of these animals may also have been infected with liver flukes. The deer released after this study were not radio-collared so it is not known if any mortalities occurred. Chambers and Barrett (1977) found that 20 of 549 pronghorns captured by drivetrapping died of capture myopathy. Mean AST values for drive-trapped versus hand-reared pronghorns were 251.5 and 31.3 respectively, and mean CK values for similar animals were 
432.1 and 10.4. Animals captured during this study had mean AST and CK values of 329.5 and 1160.9 respectively. The maximum AST value for drive-trapped antelope was 7250.0 and the maximum CK value was 2517.5 compared to the maximum values for this study of 2040 and 15490 for AST and CK respectively. Chambers and Barrett (1977) did not indicate which animals died or speculate as to an AST or CK value above which death occurred, and comparisons between pronghorns and white-tailed deer need to be taken in context because pronghorns appear to be more susceptable to capture myopathy than do white-tailed deer (Williams and Thorne, 1996). Therefore, based on AST and CK values in this study, it appears that at least one male white-tailed deer probably had some form of acute to chronic capture myopathy.

Sorbitol dehydrogenase (SDH) is a enzyme found only in the liver. Increases in SDH indicate active liver necrosis (Cornelius, 1989). Nineteen of 20 deer had SDH values greater than ine 1 eference range of 4.3-15.4 reported for cows. SDH values were over $200^{\circ} \mathrm{U} / \mathrm{L}$ in one deer and over $100 \mathrm{U} / \mathrm{L}$ in nine animals. The remaining nine deer with elevated SDH had values ranging from 62.0-94.0. One possible source of hepatic damage is infestation with liver flukes (Fascioloides magna). Liver flukes were found in six of the eight deer examined on the refuge in 1996 (Glaser and Creekmore, 1996, unpubl. data) and nine of 10 adult deer necropsied in 1983 (Foreyt, unpubl. data). Younger fawns unusually. are not infected with the parasite due to it's extremely slow growth. The prepatent period of $F$. magna in deer is approximately seven months (Foreyt, 1981). Two of the deer captured during this study were approximately nine months old and both animals had SDH levels over $100 \mathrm{U} / \mathrm{L}$. However, at nine months of age, these two deer were old enough to possibly have $F$. Magna induced liver damage.

Hematology involves primarily the evaluation of the cellular component of the blood including red and white blood cells, and platelets. To evaluate the RBC component, three basic measurements are made and include a count of the red blood cells (RBCs), an evaluation of the hemoglobin (HGB) within the cell which is the oxygen-carrying capacity of the RBC, and determining the percentage of RBCs in whole blood (the relative RBC mass) which is the hematocrit (HCT). The remaining parameters associated with the evaluation of RBCs, the mean corpuscular volume (MCV), the mean corpuscular hemoglobin $(\mathrm{MCH})$, and the mean corpuscular hemoglobin concentration $(\mathrm{MCHC})$ are all calculated values using the primary measurements of the RBC count, HCT, and HGB. Poikilocytosis is a visual evaluation of the variation in shape of $\mathrm{RBCs}$ on a blood smear. The variation is roughly quantified when compared to the normal biconcave disc shape of a $\mathrm{RBC}$. The results are reported as slight, moderate, or marked poikilocytosis. White-tailed deer are a species well-known for having a variety of shape deformities from the "normal" RBC (Kitchen, 1986). The white blood cell (WBC) evaluation includes actual counts of the total number of WBCs and then compares the relationship of the five types of cells to one another in percentages as well as absolute numbers of each cell type. The relationship between WBCs and their total numbers provides insight into infectious, parasitic, or chronic disease processes that may be ongoing in the animal. Platelets are counted to determine if cell numbers are in sufficient quantities to provide normal blood coagulation.

Red blood cell counts were higher than normal in 5 of the 20 deer tested (Table 8). These levels were only slightly higher than normal values reported by Seal (1981), and are within the range for normal male white-tailed deer over a year of age sampled in Florida by Kitchen (1986). Increased $\mathrm{RBC}$ levels can occur with hemoconcentration caused by dehydration from nutritional deprivation and weight loss. This was seen in hematological values in free-ranging white-tailed deer in Minnesota in March (DelGuidice et al., 1992). Increased stress with handling also has been reported to cause hemoconcentration (Seal et al., 1972), but stress was also shown to decrease these same hematological values (Seal et al., 1981). Nine of 20 deer had slightly 
elevated HCT values which could also be attributed to the above mentioned factors affecting the $\mathrm{RBC}$ count. The value of HGB should be roughly one third that of the HCT and the calculation of $\mathrm{MCHC}$ reflects this relationship. However, the $\mathrm{MCHC}$ calculation was found to be low in 13 of 20 deer tested when compared to our reference range (Seal et al.,1981) but was within the normal limits of 30-36 gm/dl given for all mammals (Kirk and Bistner, 1985). The MCV is the average volume of an average RBC. Nine of 20 deer had slightly elevated MCV values with the mean of this sampling falling within the normal range. Cell size and shape can vary widely among the artiodactylids.

White blood cell (WBC) counts were elevated in 13 of 20 animals tested and highly elevated in 3 deer. The cells comprising the major component of the WBC count are the neutrophil and lymphocyte. The neutrophil percentage is low in comparison to the reference range (Bubenik and Brownlee, 1987) but within the reference range (Seal et al., 1981) for the absolute number of neutrophils for 18 of 20 deer. The lymphocyte percentage and the absolute lymphocyte number are both elevated in 10 of 20 deer. Elevated lympocyte counts occur most commonly due to chronic infections or a physiologic response to fear, excitement, or handling (Kirk and Bistner, 1985). Given the activity related to capture of these animals and the abscence of any evidence of a chronic disease problem in these populations, it would seem that the elevated lymphocyte count would be most likely related to a physiological stress response. Monocytes were also elevated in 19 of 20 deer tested. Elevation of this cell type has been associated with acute stress or chronic inflammation. The type of WBC most elevated from the reference range in both the percentage and absolute numbers is the eosinophil. This cell type was found to be elevated in all 20 deer evaluated. Elevations of eosinophils are most often associated with parasitism or allergies (Kirk and Bistner, 1985). An increase in eosinophils, eosinophilia, has been directly associated with liver fluke infestation in a study of fawns (Seal et al., 1981). Liver fluke infestations were seen in 6 of 8 CWTD necropsied in 1996 on this refuge (Glaser, Creekmore, 1996, unpubl. data), and it is likely that the eosinophilia seen in this population is attributable to this parasitic infection. Together, the lymphocytes and eosinophils comprised from 50 to $79 \%$ of the total number of WBCs in 17 of 20 deer evaluated. These two types of cells should normally comprise $26-42 \%$ of the WBC count. The percentage of basophils were within the normal range but elevated in their absolute number. The number of absolute basophils is derived by calculating the percentage of basophils in the WBC count, which was generally elevated in most deer. Little is known about the significance of levels outside the normal range for basophils.

Platelets are essential for normal blood coagulation. Platelets were found to be adequate for 19 of 20 deer tested. A decreased platelet level was observed in 1 deer and was likely due to the partially clotted sample used for this evaluation. A real decrease in the number of platelets can result in an increased bleeding time and prolonged clot formation. Plasma protein levels were found to be slightly elevated in 7 of 20 deer tested. This level may be due to the hemoconcentration effect described earlier in discussing the above normal RBC count and HCT. 


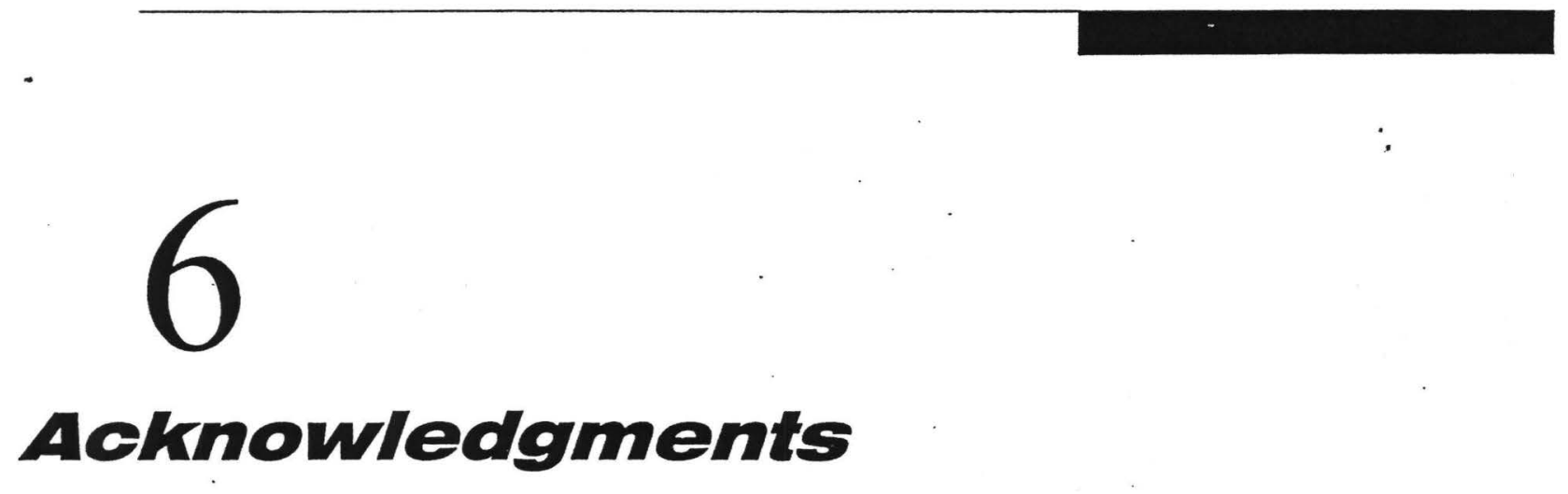

We would like to thank the staff of the Julia Butler Hansen Refuge for the Columbian Whitetailed Deer, especially Joel David, Al Clark and Tom Yollasch, for all their work and assistance during this project. Drs. Terry Hensley from the USDA Vet Services and Briggs Hall from the Washington Department of Fish and Wildlife (WDFW) provided veterinary assistance. Ray Pleasant (Weyerhauser Inc.) and Pat Miller (WDFW) provided expertise in helicopter persuit. We would also like to thank the many volunteers from the USFWS who helped move and setup nets and restrain deer. We are indebted to Drs. Lynn Creekmore, Roser Velarde, and W.R. Davidson for critical review of this report. 
Table 1 - General Information

\begin{tabular}{|c|c|c|c|c|c|c|c|c|c|c|c|c|c|c|c|c|c|c|c|c|}
\hline & 1 & 2 & 3 & 4 & 5 & 6 & 7 & 8 & 9 & 10 & $\overline{111}$ & 12 & 13 & 14 & 15 & 16 & 17 & 18 & 19 & 20 \\
\hline Location & Mainland & Mainland & Mainland & Mainland & Ten. is." & Mainland & \begin{tabular}{|l|} 
Mainland \\
\end{tabular} & Mainland & Mainland & Mainland & Ten. Is. & Ton. 18. & Ten. 18. & Ten. is. & Ten. Is. & Ten. is. & Ten. 18. & Ten. Is. & Ten. 18. & Ten. Is. \\
\hline Sex & Female & Female & Female & Female & Female & Male & Female & Female & Female & Female & Female & Female & Female & Male & Male & Male & Male & Male & Fermale & Formale \\
\hline Age & Adult & Adult & Adult & Adult & Adult & Adult & Adult & Adult & Fawn & Fawn & Adult & Adult & Adult & Adult & Adult & Adult & Adult & Adult & Adult & Adult \\
\hline Phys. Condition & Fair & Fair & Poor & Fair & Fair & Poor & Poor & Fair & Fair & Fair & Fair & Fair & Poor & Fair & Poor & Poor & Poor & Fair & Fair & Fair \\
\hline
\end{tabular}

*Tenasillahe Island

Table 2 - DAPA and Fecal Nitrogen Analysis*

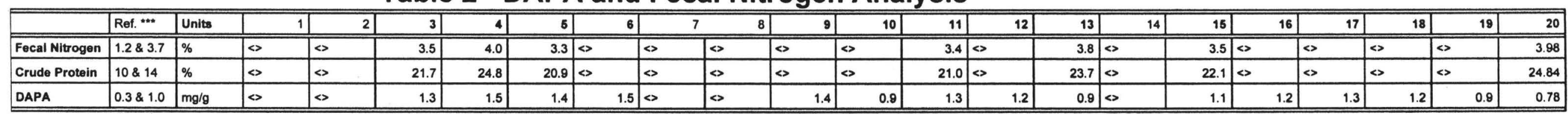

"Analyses performed by the Washington State University Wild life Health Laboratory, Pullman, Washington

$<$ No Data

***' Reference values

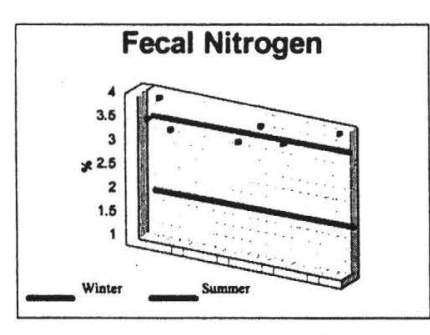

Reference Values are from Leslie et al. (1989)

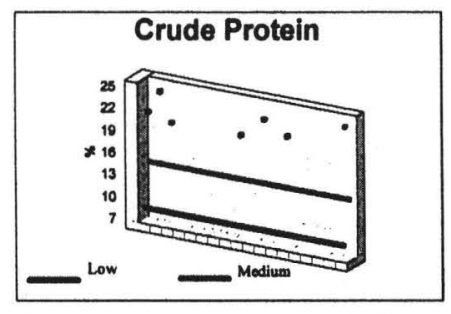

Reference values from Brown of al. (1995)

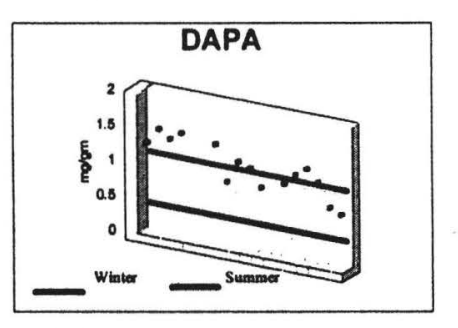

Reference values from B. Davitt (pers. comm.)

Table 3 - Progesterone

\begin{tabular}{|c|c|c|c|c|c|c|c|c|c|c|c|}
\hline Units & 1 & 2 & 3 & 4 & 7 & 11 & 12 & 18 & 20 & Mean & SD \\
\hline nmol/L* & 12 & 1 & 3 & 16 & 11 & 12 & 20 & 1 & 12 & 0 & 0 \\
\hline \multirow[t]{4}{*}{$\mathrm{ng} / \mathrm{ml}^{\prime *}$} & $8 \pi)^{2}$ & 6 & 0.24 & 6108 & 68) & 6.7. & $6 \mathrm{k} 2$ & (2). & 678 & 3.07 & 2.11 \\
\hline & \multicolumn{11}{|c|}{ Pregnant $(>1.8 \mathrm{ng} / \mathrm{ml})^{\star * *}$} \\
\hline & \multicolumn{11}{|c|}{ Not Pregnant $(<0.85 \mathrm{ng} / \mathrm{ml})$} \\
\hline & \multicolumn{11}{|c|}{ Equivocal } \\
\hline \multicolumn{12}{|c|}{ "Analyses performed by the Animal Health Diagnostic Laboratory, Lansing, Michigan } \\
\hline \multicolumn{12}{|c|}{${ }^{* \star}$ Calculated values for comparison to reference values } \\
\hline \multicolumn{12}{|c|}{ *** Reference values from Wood et al. (1986) } \\
\hline
\end{tabular}


Table 4 - Serum Vitamin E and Selenium Analyses*

\begin{tabular}{|c|c|c|c|c|c|c|c|c|c|c|c|c|c|c|c|c|c|c|c|c|c|c|c|c|}
\hline Test & Units & Ref. ${ }^{* \star *} \sim$ & 1 & 2 & 3 & 4 & 5 & 6 & 7 & 8 & 9 & \begin{tabular}{l|l}
10 \\
\end{tabular} & 11 & 12 & 13 & 14 & 15 & \begin{tabular}{|l|l|}
16 \\
\end{tabular} & 17 & \begin{tabular}{|l|}
18 \\
\end{tabular} & 19 & 20 & Moan & So \\
\hline Selenium & $\mathrm{ng} / \mathrm{ml}$ & $100-120^{* * *}$ & $x^{2}$ & 3 & 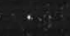 & W & & & & , & os & 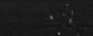 & & & & & & & & & & & 39 & 12.7 \\
\hline Vit E & $\mathrm{ug} / \mathrm{ml}$ & $2.0-6.0 \sim$ & 2.44 & 2.50 & 2.50 & 2.73 & 2.49 & $\ll$ & & $\ll$ & $\ll$ & $\ll$ & $\ll$ & $\ll$ & $\ll$ & 2.68 & 2.74 & 2.36 & & 2.62 & 2.88 & $\ll$ & 2.52 & 0.33 \\
\hline
\end{tabular}

\begin{tabular}{l|lll|l|l|l|l|l} 
Vitt & $\mathrm{ug} / \mathrm{ml}$ & $2.0-6.0 \sim$ & 2.44 & 2.50 & 2.50 & 2.73 & 2.49 & $<$ \\
\hline * Analyses performed by the Animal Health Diagnostic Laboratory , Lansing, Michigan
\end{tabular}

**Reference values from Puls, 1994

$\sim$ Reference values from the Animal Health Diagnostic Laboratory, Lansing Michigan

$<$ No Data

Above Reference Range (Of significance)

Above Reference Range

Below Reference Range (Of Significance)

Below Reference Range
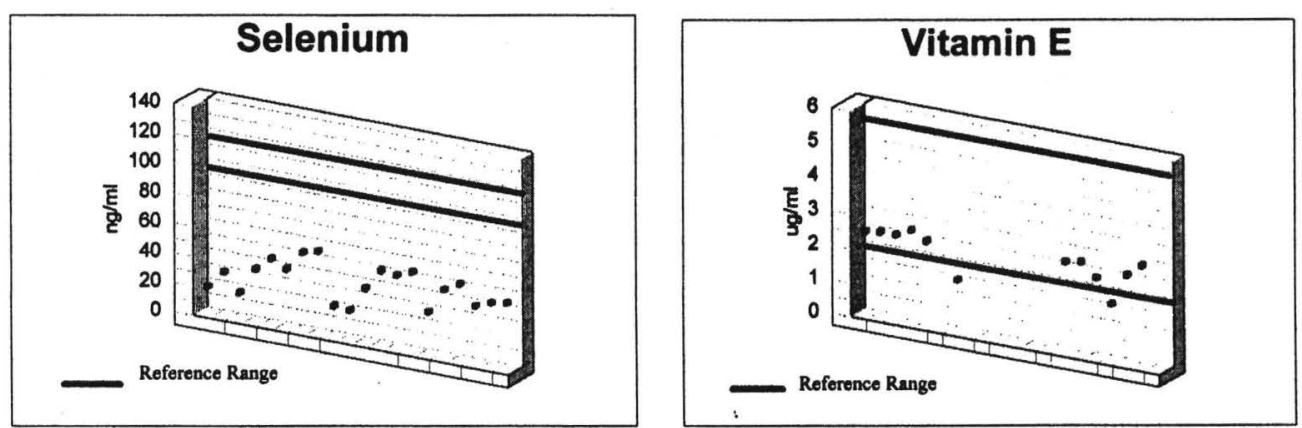
Table 5 Trace Minerals*

\begin{tabular}{|c|c|c|c|c|c|c|c|c|c|c|c|c|c|c|c|c|c|c|c|c|c|c|c|}
\hline & Reff. - & 1 & 2 & 3 & 4 & 5 & 6 & 7 & 8 & 9 & 10 & 11 & 12 & 13 & 14 & 15 & 16 & 17 & 18 & 19 & 20 & Moan & so \\
\hline Calcium"* & $85-130$ & 81.1 & 80.3 & 807 & 816 & 775 & 89.2 & 86.2 & 841 & 823 & $7 \pi 4$ & 84.8 & $\ll$ & 84.4 & 84.6 & $\ll$ & 91.4 & 824 & 89.1 & 837 & 85.4 & 83.7 & 3.76 \\
\hline Phos & $44-90$ & 73.1 & 59.5 & 66.3 & 61.2 & 53.1 & 64.7 & 55.0 & 72.9 & 62.6 & 44.8 & 73.1 & $\ll$ & 67.7 & 66.3 & $\Leftrightarrow$ & 68.8 & 67.2 & 78.7 & 87.9 & 64.6 & 86.0 & 9.75 \\
\hline Copper & $0.6-1.3$ & 50.050 & 0.989 & 0.501 & 0353 & $<0.050$ & 0.139 & 01173 & 1.12 & 0.72 & 0.828 & 0101 & $\ll$ & 0.104 & 40.050 & $\ll$ & 0.172 & 20.050 & 0.088 & $<0.050$ & $<0050$ & 0.290 & 0.37 \\
\hline Zine & $0.5-1.0$ & 0.374 & 0.344 & 0.537 & 0.826 & 0.487 & 0.356 & 0.843 & 0.472 & 0.5 & 0.482 & 0.374 & $\Leftrightarrow$ & 0.458 & 0.682 & $\Leftrightarrow$ & 0.407 & 0.715 & 0.487 & $\begin{array}{r}0.359 \\
\end{array}$ & 0.474 & 0.520 & 0.17 \\
\hline Iron & 1.52-2.77 & 1.59 & 1.02 & 1.45 & 2.76 & 2.73 & 1.38 & 1.96 & 1.95 & 2.09 & 2.16 & -1.31 & $\ll$ & 1.88 & 0.817 & $\ll$ & 1.59 & 0.825 & 1.78 & 0.071 & 2.129 & 1.63 & 0.6 \\
\hline Sodium & $3174-3460$ & 3400 & 3290 & 3270 & 3210 & 3300 & 3070 & 3080 & 2060 & 2840 & 3000 & 3290 & $\Leftrightarrow$ & 3380 & 3300 & 《> & 3260 & 3320 & 3330 & 3390 & 3230 & 3222 & 148.18 \\
\hline Magnesium & $18-28$ & 70.1 & 51.6 & 687 & 57.5 & 287.0 & 63.1 & 288.4 & 60.01 & 1280 & 70.1! & 63:계 & $<>$ & 22.2 & 22.2 & $\ll$ & 24.5 & 1220 & 23.4 & 22.8 & 25.4 & 70.7 & 62.46 \\
\hline Potassium & $148-312$ & 175 & 186 & 231 & 155 & 207 & 625 & -482 & 867 & 605: & 456 & 155 & $\Leftrightarrow$ & 213 & 203 & $\Leftrightarrow$ & 219 & 174 & 261 & 223 & 213 & 295 & 162.89 \\
\hline
\end{tabular}

" Analyses performed by the Animal Health Diagnostic Laboratory, Lansing, Michigan

** Trace Mineral values are in ppm

$\sim$ Reference Values are from Puls (1994)

< No data due to insufficient sample

Above Reference Values (Of Significance)

Above Reference Values

Below Reference Values (Of Significance)

Below Reference Values

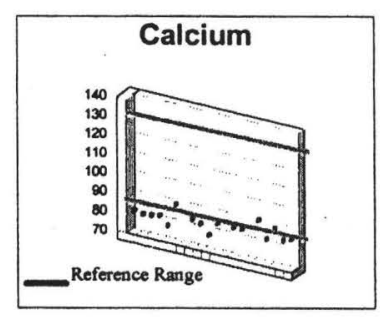

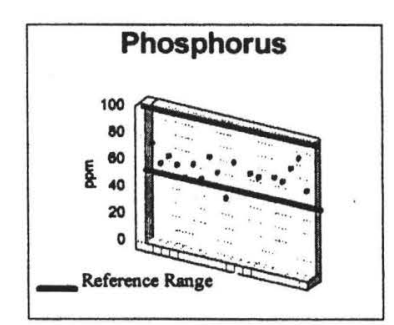
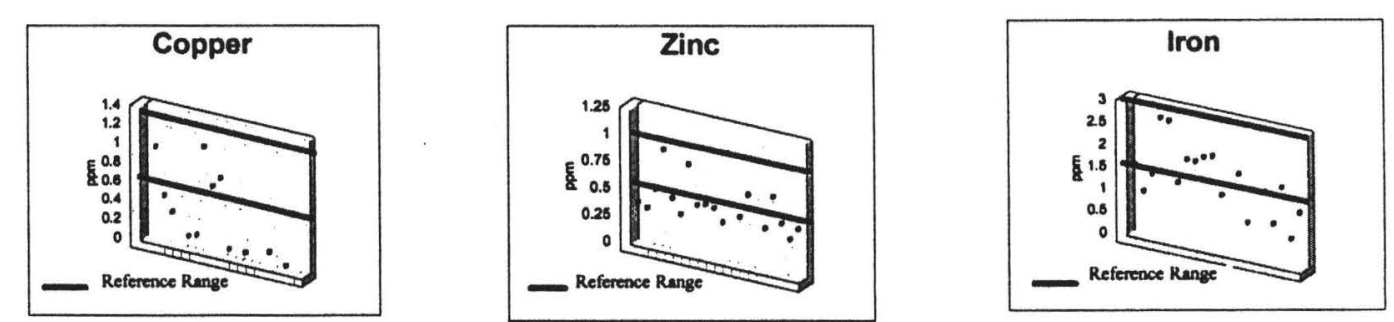

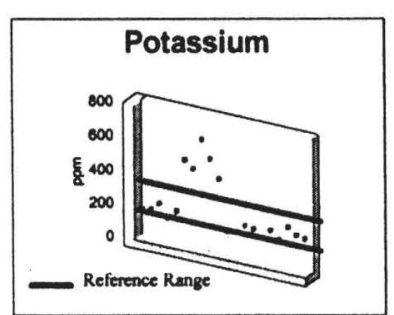


Table 6 - Leptospira Serology*

\begin{tabular}{|c|c|c|c|c|c|c|c|c|c|c|c|c|c|c|c|c|c|c|c|c|}
\hline & 1 & 2 & 3 & 4 & 5 & 6 & 7 & 8 & 9 & 10 & 11 & 12 & 13 & 14 & 15 & 16 & 17 & 18 & 19 & 20 \\
\hline L. bra & $<100$ & $<100$ & $<100$ & $<100$ & $<100$ & $<100$ & $<100$ & $\mid<100$ & $<100$ & $<100$ & $<100$ & $<100$ & 200 & 35e0 & $<100$ & $<<100$ & $<<100$ & $<100$ & $<100$ & 400 \\
\hline L. can & $<100$ & $<100$ & $<100$ & $<100$ & $<100$ & $<100$ & $<100$ & $<100$ & $<100$ & $<100$ & $<100$ & $<100$ & $<100$ & $<100$ & $<100$ & $<100$ & $<100$ & $<100$ & $<100$ & $<100$ \\
\hline L.gri & $<100$ & $<100$ & $<100$ & $<100$ & 800 & $<100$ & $<100$ & ${ }^{2}=400$ & $<100$ & $<100$ & $<100$ & $<100$ & $<100$ & $<100$ & $<100$ & $<100$ & $<100$ & 100 & $<100$ & $<100$ \\
\hline L. har & $<100$ & $<100$ & $<100$ & $<100$ & $<100$ & $<100$ & $<100$ & $<100$ & $<100$ & $<100$ & $<100$ & $<100$ & $<100$ & $7 \times 100$ & $<100$ & $<100$ & $<100$ & $<100$ & $<100$ & $<100$ \\
\hline L. ict & $<100$ & $<100$ & $\mid<100$ & $<100$ & $<100$ & $<100$ & $<100$ & $<100$ & $<100$ & $<100$ & $<100$ & $<100$ & $<100$ & $<100$ & $<100$ & $\mid<100$ & $<100$ & $<100$ & $<100$ & $<100$ \\
\hline L. pom & 800 & $<100$ & $<100$ & $<100$ & $<100$ & $<100$ & $<100$ & $<100$ & $<100$ & $<100$ & $<100$ & $<100$ & 200 & 1. 3200 & $<100$ & $<100$ & $<100$ & $<100$ & $<100$ & 800 \\
\hline
\end{tabular}

*Analyses performed by the Wisconsin Animal Health Laboratory, Madison, Wisconsin

Positive titer (Of significance)

Positive titer

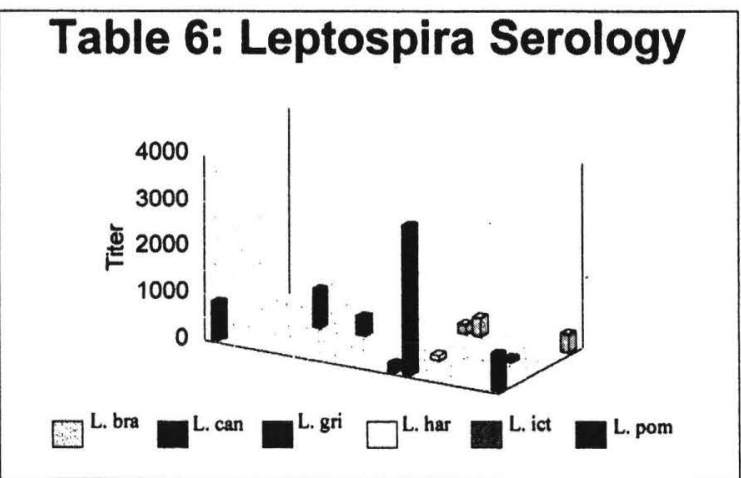

$\begin{array}{ll}\text { Abbreviation } & \text { Serovar } \\ \text { L. bra } & \text { L. bratislava } \\ \text { L. can } & \text { L. canicola } \\ \text { L. gri } & \text { L. grippotyphosa } \\ \text { L. har } & \text { L. harjo } \\ \text { L. ict } & \text { L. icterohemormagiae } \\ \text { L. pom } & \text { L. pomona }\end{array}$


Table 7 Fecal Parasites/ Deer*

\begin{tabular}{|c|c|c|c|c|c|c|c|c|c|c|c|c|c|c|c|c|c|c|c|c|}
\hline Fecal Parasites" & 11 & 2 & 3 & 41 & 5 & 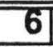 & 7 & 8 & 91 & 101 & 11 & 12 & 131 & 741 & 15 & 161 & 17 & 78 & 19 & 20 \\
\hline Fecal Strongyloides sp. eggs & 0 & $<$ & 0 & 이 & 0 & 1 & $\ll$ & $\ll$ & 4 & 0 & 0 & 0 & 0 & $\ll$ & 0 & 0 & 1 & 1 & 1 & 0 \\
\hline Strongyle eggs & 11 & $\ll$ & 1 & 11 & 3 & 9 & $\ll$ & $\ll$ & 91 & 59 & 6 & 19 & 1 & $\ll$ & 38 & 24 & 20 & 17 & 4 & 14 \\
\hline \begin{tabular}{|l|} 
Larval stage 1 w/ spine \\
Parelaphostrongylus sp. \\
\end{tabular} & 0 & $<>$ & 10 & 0 & 2 & 0 & $\ll$ & $<$ & 0 & 0 & 4 & 1 & 0 & $\ll$ & 0 & 0 & 1 & 0 & 0 & 0 \\
\hline $\begin{array}{l}\text { Larval Stage } 1 \\
\text { Dictyocaulus }\end{array}$ & 0 & $<$ & 16 & 0 & 0 & 0 & $<$ & $\Leftrightarrow$ & 0 & 0 & 0 & 0 & 0 & 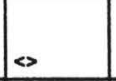 & 0 & 0 & 0 & 0 & 0 & 0 \\
\hline Trichuris sp. eggs & 0 & $\ll$ & 1 & 0 & 0 & 0 & $\ll$ & $\Leftrightarrow$ & 1 & 0 & 0 & 0 & 0 & $<$ & 0 & 0 & 1 & 8 & 2 & 0 \\
\hline Capillaria sp. eggs & 0 & $\ll$ & 0 & 0 & 0 & 0 & $<$ & $\Leftrightarrow$ & 1 & 0 & 0 & 0 & 0 & $\Leftrightarrow$ & 0 & 0 & 0 & 0 & 0 & 0 \\
\hline $\begin{array}{l}\text { Coccidia (Eimerila sp.) } \\
\text { unsporulated }\end{array}$ & 0 & $\ll$ & 0 & 0 & 0 & 0 & $<$ & $\ll$ & 0 & 1 & 0 & 0 & 0 & $\Leftrightarrow$ & 0 & 0 & 2 & 0 & 0 & 0 \\
\hline Trematode eggs & 0 & $\Leftrightarrow$ & 0 & 0 & 0 & 0 & $\Leftrightarrow$ & $<$ & 0 & 0 & 0 & 0 & 0 & $\Leftrightarrow$ & 0 & 0 & 2 & 0 & 0 & 1 \\
\hline
\end{tabular}

* Analyses performed by the USGS BRD National Wildlife Health Center, Madison, Wisconsin

$<$ Inadequate sample available to perform analyses. 
Table 8 - Serum Chemistry Results*

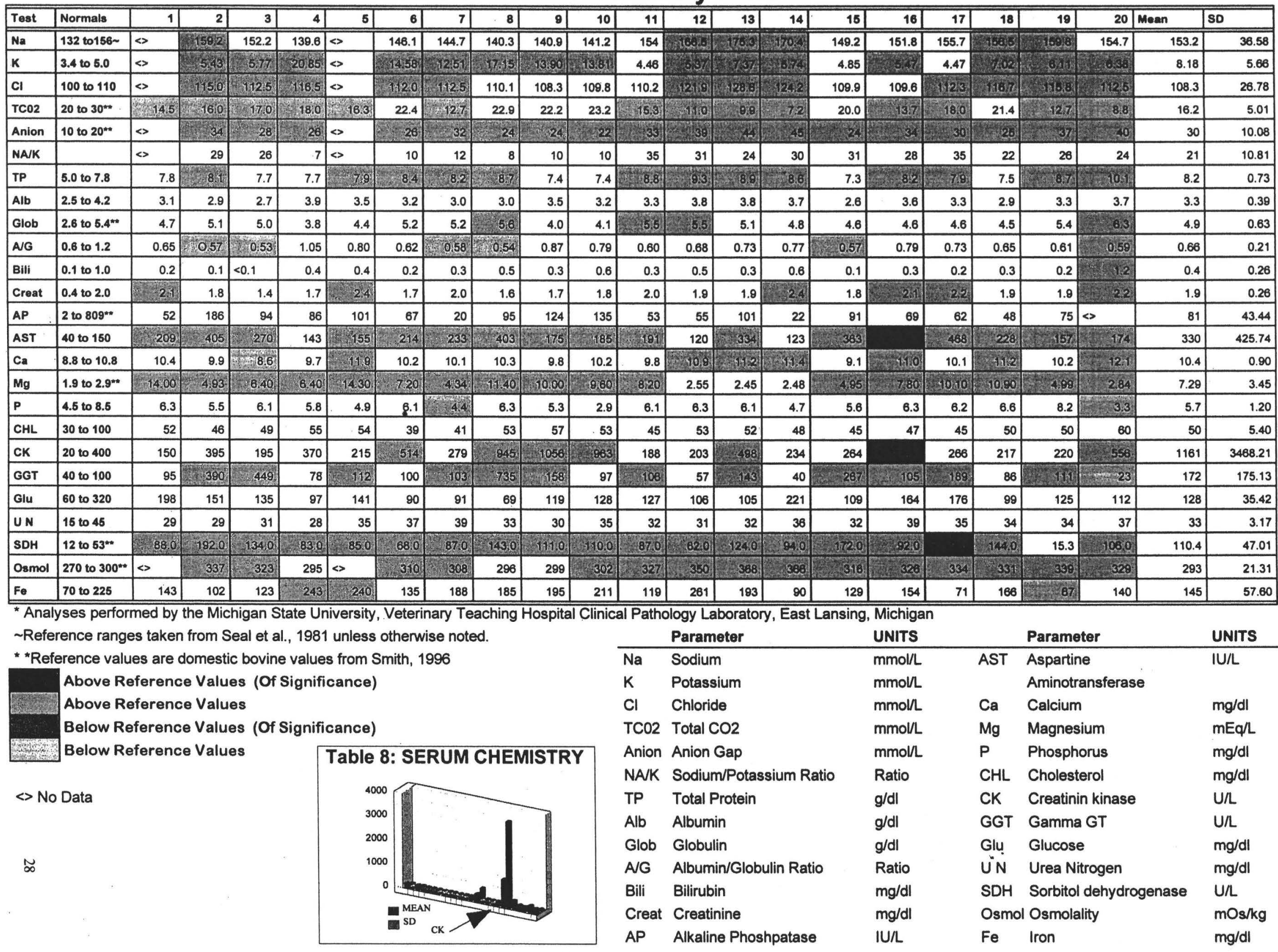


Table 9 - Hematology Results*

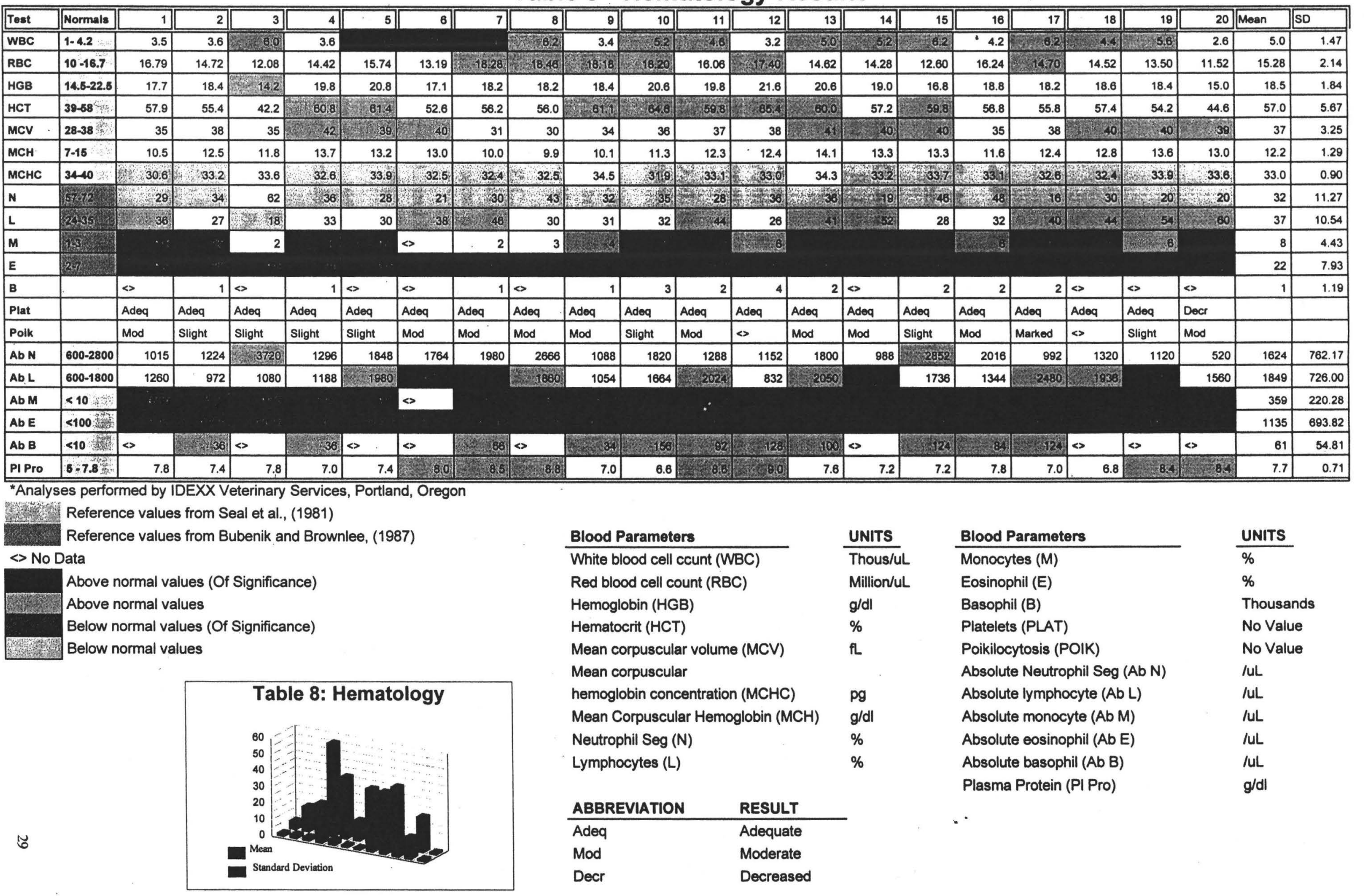




\section{7}

\section{Literature Cited}

Anderson, A.E., Medin, D.E., and D.C. Bowden. 1972. Erythrocytes and leukocytes in a Colorado mule deer population. Journal of Wildlife Diseases 8:183-190.

Anderson, R.C., and A.K. Prestwood. 1981. Lungworms. In Diseases and Parasites of Whitetailed Deer, W.R. Davison, F.A. Hayes, V.F. Nettles, and F.E. Kellogg (eds.). Tall Timbers Research Station, Tallahassee, Florida, pp. 266-317.

Bergstrom, R.C., and R.F. Honess. 1982. Gastrointestinal Nematodes. In Diseases of Wildlife in Wyoming, E.T. Thorne, N. Kingston, W.R. Jolley, and R.C. Bergstrom (eds.). Wyoming Game and Fish Department, Cheyenne, Wyoming, pp.191-193.

Blood, D.C., O.M. Radostits, and J.A. Henderson. 1983. Veterinary Medicine. Bailliere Tindall, Eastbourne, England.

Brady, P.S., L.J. Brady, P.A. Whetter, D.E. Ullrey, and L.D. Fay. 1978. The effect of dietary selenium and vitamin $\mathrm{E}$ on biochemical parameters and survival of young among whitetailed deer (Odocoileus virginianus). Journal of Nutrition 108:1439-1448.

Brown, R.D., E.C. Hellgren, M. Abbott, D.C. Ruthven, and R.L. Bingham. 1995. Effects of dietary energy and protein restriction on nutritional indices of female whitetailed deer. Journal of Wildlife Management 59:595-609.

Bubenik, G. A. and L. Brownlee. 1987. Assessing health of male white-tailed deer by white blood cell counts. Journal of Wildlife Management. 51: 945-949.

Carlson, G.P. 1989. Fluid, Electrolyte, and Acid-Base Balance. In Clinical Biochemistry of Domestic Animals, J.J. Kaneko (ed.). Academic Press, San Diego, California. pp 543-575.

Carlson, G.P. 1996. Clinical Chemistry Tests. In Large Animal Internal Medicine, B.P. Smith (ed.). Mosby Year Book, St. Louis, Missouri, pp 441-469.

Chalmers, G.A., and M.W. Barrett. 1977. Capture myopathy in pronghorns in Alberta. Journal of the American Veterinary Medical Association. 171:918-923.

Cornelius, C.E. 1989. Liver Function. In Clinical Biochemistry of Domestic Animals, J.J. Kaneko (ed.). Academic Press, San Diego, California. pp 364-397. 
, Burnham, L.G., and H.E. Hill. 1963. Serum transaminase activities of thoroughbred horses in training. Journal of the American Veterinary Medical Association. 142: 639-642.

Davidson, W.R. and V.F. Nettles. 1997. Miscellaneous Bacterial and Rickettsial Diseases. In Field Manual of Wildlife Diseases in the Southeastern United States. Southeastern Cooperative Wildlife Disease Study, University of Georgia, Athens, Georgia. pp.49-50.

Davitt, B.B., and J.R. Nelson. 1984. Methodology for the determination of DAPA in feces of large ruminants. Pages 133-147 in R.W. Nelson, ed. Proceedings 1984 western states and - provinces elk workshop. Alberta Fish and Wildlife, Edmonton, Alberta, Canadá.

DelGuidice, G. D., L. D. Mech, K. E. Kunkel, E. M. Gese, U. S. Seal. 1992. Seasonal patterns of weight, hematology, and serum characterisitics of free-ranging female white-tailed deer in Minnesota. Canadian Journal of Zoology Vol. 70, pp974-983.

DeLiberto, T.J., Pfister, J.A., Demarais, S., and Van Vreede, G. 1989. Seasonal changes in physiological parameters of white-tailed deer in Oklahoma. Journal of Wildlife Management 53:533-539.

Foreyt, W.L. 1981. Trematodes and Cestodes. In Diseases and Parasites of White-tailed Deer, W.R. Davison, F.A. Hayes, V.F. Nettles, and F.E. Kellogg (eds.). Tall Timbers Research Station, Tallahassee, Florida, pp. 237-265.

Gavin, Thomas A. 1984. Pacific Northwest. In White-tailed Deer Ecology and Management, ed. L.K. Halls, pp.487-496. Harrisburg, PA.:Stackpole Books. 870pp.

Haigh, J.C., R.R. Stewart, G. Wobeser, and P.S. MacWilliams. 1977. Capture myopathy in a moose. Journal of the American Veterinary Medical Association. 171: 924-926.

Hoffman, R. A., and P.F. Robinson. 1966. Changes in some endrocrine glands of white-tailed deer as affected by season, sex, and age. Journal of Mammology. 47:266-280.

Honess, R.F. 1982. Capillariasis. In Diseases of Wildlife in Wyoming, E.T. Thorne, N. Kingston, W.R. Jolley, and R.C. Bergstrom (eds.). Wyoming Game and Fish Department, Cheyenne, Wyoming, pp.191-193.

Kingston, N. 1981. Protozoan Parasites. In Diseases and Parasites of White-tailed Deer, W.R. Davison, F.A. Hayes, V.F. Nettles, and F.E. Kellogg (eds.). Tall Timbers Research Station, Tallahassee, Florida, pp.193-236.

Kirk, R. W., and S. I. Bistner. 1985. Veterinary Procedures \& Emergency Treatment. 4th edition. Published by W. B. Saunders Co., Philadelphia, PA.

Kitchen, H. 1986. Hematological Values and Blood Chemistries for a Variety of Artiodactylids. Zoo \& Wild Animal Medicine. 2nd edition. Murray E. Fowler, editor. Published by W.B. Saunders. Philadelphia, PA 
Kucera, T.E. 1997. Fecal indicators, diet, and population parameters in mule deer. Journal of Wildlife Management 61:550-560.

Leslie, D.M., and E.E. Starkey. 1985. Fecal indicies to dietary quality of cervids in old-growth forests. Journal of Wildlife Management 49:142-148.

, J.A. Jenks, M.Chilelli, and G.R. Lavigne. 1989. Nitrogen and diaminopimelic acid in deer and moose feces. Journal of Wildlife Management 53:216-218.

Mould, E.D., and C.T. Robbins. 1981. Nitrogen metabolism in elk. Journal of Wildlife Management 45:323-334.

Murphy, D. A., and J. A. Coates. 1966. Effects of dietary protein on deer. Transcripts of the North American Wildlife and Natural Resources Conference. 31:129-139.

Prestwood, A.K., and S.R. Pursglove, JR. 1981. Gastrointestinal nematodes. In Diseases and Parasites of White-tailed Deer, W.R. Davison, F.A. Hayes, V.F. Nettles, and F.E. Kellogg (eds.). Tall Timbers Research Station, Tallahassee, Florida, pp. 318-350.

Platt, T.R., and W.M. Samuel. 1978. Parelaphostrongylus odocoilei: Life cycle in experimentally infected cervids including mule deer, Odocoileus h. hemionus. Experimental Parasitology 46: 330-338.

Plotka, E.D., U.S. Seal, L.J. Verme, and J.J. Ozoga. 1983. The adrenal gland in white-tailed deer: a significant source of progesterone. Journal of Wildlife Management 47:38-44.

Puls, R. 1988. Mineral levels in Animal Health: diagnostic data. Sherpa International, Clearbroo, B.C., Canada, 240 pp. Canada, 356 pp.

1994. Mineral levels in Animal Health, 2nd ed. Sherpa International, Clearbroo, B.C.,

Robbins, C.T., S.M. Parish, and B.L. Robbins. 1985. Selenium and glutathione peroxidase activity in mountain goats. Canadian Journal of Zoology 63:1544-1547.

- 1993. Wildlife Feeding and Nutrition, 2nd ed. Series of Monographs, Cunha, T.J. (ed.). Academic Press, Inc., San Diego, California, 352 pp.

Roth, E.E. 1970. Leptospirosis. In Infectious Diseases of Wild Mammals. J.W. Davis (ed.). Iowa State University Press, Ames, Iowa. pp. 293-303.

Ruth, G.R. and J.F. Van Vleet. 1974. Experimentally induced selenium-vitamine E deficiency in growing swine: selective destruction of type I skeletal muscle. American Journal of Veterinary Research. 35:237-244.

Seal, U.S., J. J. Ozoga, A.W. Erickson, and L. J. Verme. 1972. Effects of Immobilization on Blood Analysis of White-Tailed Deer. Journal of Wildlife Management, Vol. 36, No.4, October 1972. pp 1034-1040. 
, L.J. Verme, and J.J. Ozoga 1981. Physiologic Values. In Diseases and Parasites of White-tailed Deer, W.R. Davison, F.A. Hayes, V.F. Nettles, and F.E. Kellogg (eds.). Tall Timbers Research Station, Tallahassee, Florida, pp. 318-350.

Severinghaus, C.W. 1949. Tooth development and wear as criteria of age in white- tailed deer. Journal of Wildlife Management 13(2):195-216.

Shotts, E.B. 1981. Leptospirosis. In Diseases and Parasites of White-tailed Deer, W.R. Davison, F.A. Hayes, V.F. Nettles, and F.E. Kellogg (eds.). Tall Timbers Research Station, Tallahassee, Florida, pp. 138-147.

.Smith, B.P. 1996. Large animal Internal Medicine, 2nd ed. Mosby year Book, St. Louis, Missouri, $2040 \mathrm{pp}$.

Statland, B.E., and P. Winkel. 1979. Sources of variation in laboratory measurements. In Clinical Diagnosis and Management by Laboratory Methods. J.B. Henry (ed.). W.B. Saunders Co. Philadelphia, Pennsylvania. pp 3-28.

Stockle, A.W., G.L. Doster and W.R. Davidson. 1978. Endogenous fat as an indicator of physical condition of Southeastern white-tailed deer. Southeastern Association of Fish and Wildlife Agencies.

Sullivan, J.B., C.A. DeYoung, S.L. Beasom, J.R. Heffelfinger, S.P. Coughlin, and M.W. Hellickson. 1991. Drive-netting deer: incidence of mortality. Wildlife Society Bulletin 19:393396.

Tasker, J.B. 1980. Fluids, electrolytes, and acid-base balance. In Clinical Biochemistry of Domestic Animals, J.J. Kaneko (ed.). Academic Press, San Diego, California. pp 401-446.

Trainer, D.O., R.P. Hanson, E.P. Pope, and E.A. Carbrey. 1963. The role of deer in the epizootiology of leptospirosis in Wisconsin. American Journal of Veterinary Research. 24:159167.

Verme, L.J. 1962. Mortality of white-tailed deer fawns in relation to nutrition. Proceedings of the National White-tailed Deer Disease Symposium. 1:15-38.

1965. Reproduction studies on penned white-tailed deer. Journal of Wildlife Management. 29:74-79.

1967. Influence of experimental diets on white-tailed deer reproduction.

Transcripts of the North American Wildlife and Natural Resources Conference. 32:405-420.

, and J.J. Ozoga. 1971. Influence of winter weather on white-tailed deer in upper Michigan. In: A.O. Haugen, ed., Proceedings, Snow and Ice in Relation to . Wildlife and Recreation symp., Ames: Iowa Cooperative Wildlife Research Unit, Iowa State University. pp. 16-28. 
and D.E. Ullrey. 1984. Physiology and Nutrition. In White-tailed Deer Ecology and Management. R.E. McCabe and L.R. Jahn (eds.). Stackpole Books, Harrisburg, Pennsylvania. pp. 119-128.

White, M., and R.S. Cook. 1974. Blood characterisitics of free-ranging White-Tailed Deer in Southern Texas. Journal of Wildlife Diseases Vol. 10, Jan. 1974 pp 18-24.

Williams, E.S. and E.T. Thorne. 1996. Exertional myopathy (capture myopathy). In Nonifectious Diseases of Wildlife. A. Fairbrother, L.N. Locke, and G.L. Hoff (eds.). Iowa State University Press, Ames, Iowa. pp. 181-193.

Wood, A.K., R.E. Short, A.-E. Darling, G.L. Dusek, D. G. Sasser, and C.A. Ruder. 1986. Serum assays for detecting pregnancy in mule and white-tailed deer. Journal of Wildlife Management 50:684-687.

\section{Personal Communication}

Clark, A. Biologist. J.B. Hansen NWR.10/21/97.

Davitt, B. Wildlife Habitat Laboratory, Washington State University 7/20/98. 